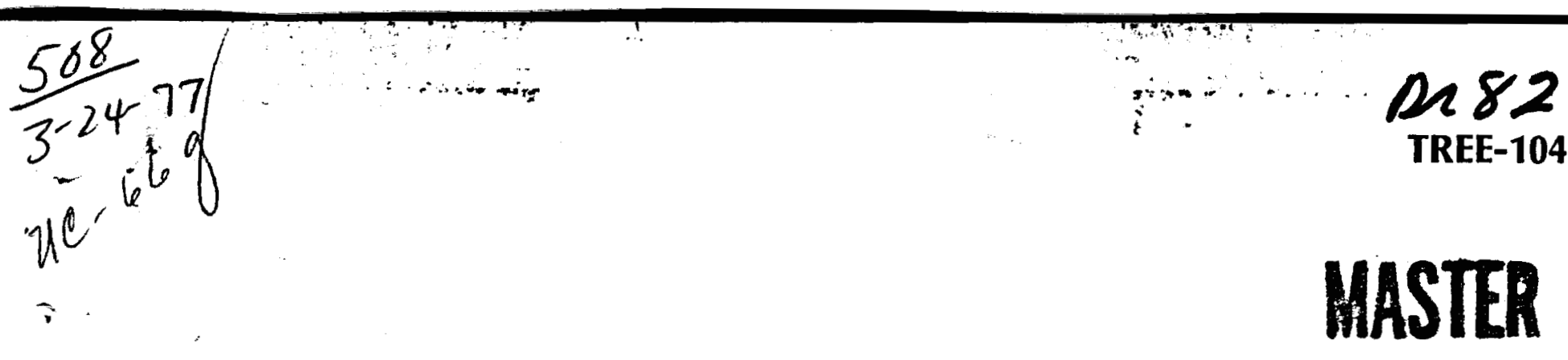

\title{
BENEFICIAL USES OF GEOTHERMAL ENERGY DESCRIPTION AND PRELIMINARY RESULTS FOR PHASE 1 OF THE RAFT RIVER IRRIGATION EXPERIMENT
}

\author{
R. C. SCHMITT S. G. SPENCER
}

January 1977

EG\&E Idaho, Inc.

IDAHO NATIONAL ENGINEERING LABORATORY

ENERGY RESEARCH AND DEVELOPMENT ADMINISTRATION

IDAHO OPERATIONS OFFICE UNDER CONTRACT EY-76-C-07-1570 


\section{DISCLAIMER}

This report was prepared as an account of work sponsored by an agency of the United States Government. Neither the United States Government nor any agency Thereof, nor any of their employees, makes any warranty, express or implied, or assumes any legal liability or responsibility for the accuracy, completeness, or usefulness of any information, apparatus, product, or process disclosed, or represents that its use would not infringe privately owned rights. Reference herein to any specific commercial product, process, or service by trade name, trademark, manufacturer, or otherwise does not necessarily constitute or imply its endorsement, recommendation, or favoring by the United States Government or any agency thereof. The views and opinions of authors expressed herein do not necessarily state or reflect those of the United States Government or any agency thereof. 


\section{DISCLAIMER}

Portions of this document may be illegible in electronic image products. Images are produced from the best available original document. 
Printed in the United States of America Available from

National Technical Information Service U.S. Department of Commerce

5285 Port Royal Road

Springfield, Virginia 22161

Price: Printed Copy $\$ 4.50$; Microfiche $\$ 3.00$

\section{NOTICE}

This report was prepared as an account of work sponsored by the United States Government. Neither the United States nor the Energy Research and Development Administration, nor the Nuclear Regulatory Commission, nor any of their employees, nor any of their contractors, subcontractors, or their employees, makes any warranty, express or implied, or assumes any legal liability or responsibility for the accuracy, completeness or usefulness of any information, apparatus, product or process disclosed, or represents that its use would not infringe privately owned rights. 


\section{TREE - 1048 - BENEFICIAL USES OF GEOTHERMAL ENERGY DESCRIPTION AND PREL IMINARY RESULTS FOR PHASE 1 OF THE RAFT RIVER IRRIGATION EXPERIMENT}

\section{APPROYED:}
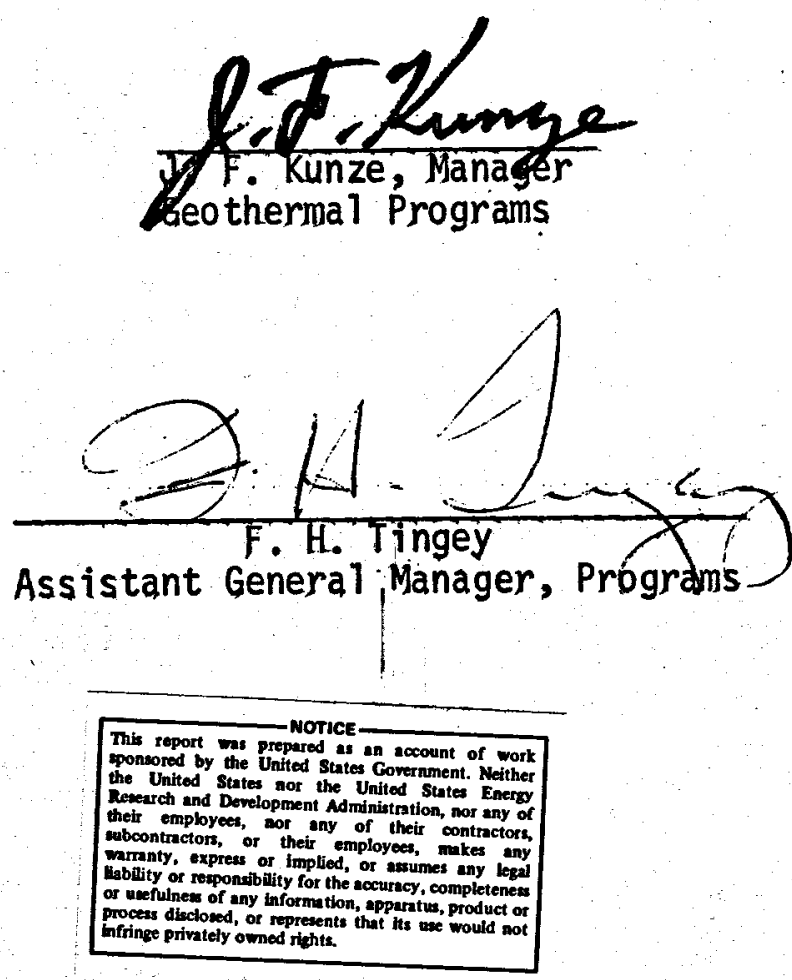


\title{
TREE-1048
}

DISTRIBUTED UNDER CATEGORY:

BENEFICIAL USES OF GEOTHERMAL ENERGY

DESCRIPTION AND PRELIMINARY RESULTS

FOR

PHASE I OF THE RAFT RIVER JRRIGATION EXPERIMENT EG\&G Idaho, Inc.

$3^{3^{81}}$

IDAHO NATIONAL ENGINEERING LABORATORY

Idaho Falls, Idaho 83401

\author{
Authors \\ R. C. Schmitt \\ S. G. Spencer \\ Date Published - January 1977 \\ Prepared for the \\ ENERGY RESEARCH AND DEVELOPMENT ADMINISTRATION \\ Under Contract No. EY-76-C-07-1570
} DIVISION OF GEOTHERMAL ENERGY AND IDAHO OPERATIONS OFFICE 


\section{ABSTRACT}

The first phase of an experiment using geothermal water for irrigation is described and preliminary results are discussed. The water was from a moderate temperature well, having salinity of about 2000 parts/million, and is considered characteristic of the types of geothermal fluids that will be obtained from the young yolcanic/young sediment formations of the northern intermountain west. The activity was completed by the Energy Research and Development Administration's Idaho National Engineering Laboratory at a location adjacent to ERDA's Raft River Geothermal Project in southern Idaho. Local farmers provided the land and part of the services through contracts with ERDA. INEL was assisted by Utah State University's Agriculture and Irrigation Engineering Department, Idaho Agriculture Extension Agents and others. The experimental crops were donated to the I daho Youth Ranch at Rupert, I daho following sampling, analyses and determining the safeness for livestock consumption.

The experiment is aimed at examining one potential for the beneficial use of geothermal waters, in water scarce areas, and may open the way to more use of this widespread resource. Success with the experiment could contribute to reducing well reinjection costs following power generation or to total use concepts in conjunction with industrial processors for low temperature resources. Possible benefits to water-starved regions of the country are evident, and the results of the experiment are expected to contribute significantly to more encompassing environmental questions surrounding the use of geothermal energy in the U.S.

About 12.5 acres, of which part had no previous cultivation, were subdivided by crops and irrigation practices for investigation with the geothermal water and a control comparison water from the relatively pure Raft River. Flood and sprinkler application techniques were used and wheat, barley, oats, grasses, alfalfa, potatos, and garden vegetables were successfully grown. An accompanying experiment evaluated the behavior of an established alfalfa crop located nearby, when most of the irrigation water was geothermal.

The experiment addressed heavy metal uptake in plants, plant fluoride retention and damage, plant tolerances to salts, soil alterations and other behavior as a result of the geothermal fluids, all of which were largely believed to eliminate geothermal water from contention for crop growing utilization. Not all analyses and results are complete in this reporting, but first results indicate no apparent difference between the geothermal watered crops and those obtained using the fresh water control. Extensive chemical analyses, neutron activation analyses, and other evaluations of crop samples are discussed, and sorie of the findings are presented. 
Although evaluation of crop yields was not an objective, extrapolations from samples indicate that yield results were comparable to those commonly found in the area, and the yield varied little between water sources.

The experiment is expected to continue for two additional years, to be reported as Phases 2 and 3 of the experiment. An additional report, summarizing data, evaluations or findings not complete for this reporting of the Phase 1 activities will be provided about mid 1977. Results of winter wheat and alfalfa planting this fall will be studied next year.

\section{ACKNOWLEDGMENTS}

The authors wish to express their appreciation to various individuals who have contributed to the successful completion of this phase of the Irrigation Experiment.

Particularly the leadership of J. F. Kunze, Manager, Geothermal Projects and R. J. Schultz, Manager, Non-Electric Geothermal Program during all phases of this experiment.

D. H. Suckling, K. E. Peterson and others on-site at the Raft River Geothermal Project who spent many trying hours manipulating irrigation systems, water and crops.

Summer student hires E. Schultz, D. Preussner and W. Bierlein who devoted attention and persistence in various sampling and crop growing activities.

Wayne Cole, Cassia County Agriculture Agent, for his interest and advice.

J. G. Keller for compilation and interpretation of the weather data found herein.

Drs. Bishop and Peterson, Utah State University Agriculture and Irrigation Engineering Department, for making available a major part of the irrigation system and for the ir able guidance and assistance throughout the experiments.

Raft Riyer farmers L. Udy, R. S. Stewart and I. Darrington, and land owner H. B. Jensen for their understanding and cooperation in making land available to site the experiment.

L. Speth, Ricks College for his in-field sampling, preparation of samples and coordination activities.

And to others who have contributed advice and encouragement during the course of this activity. 
CONTENTS

ABSTRACT . . . . . . . . . . . . . . . . . .

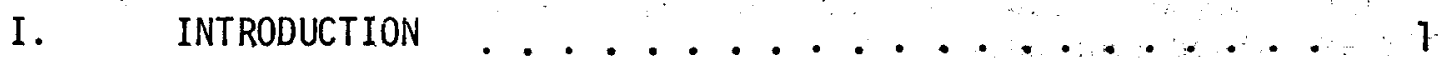

II. RAFT RIVER IRRIGATION EXPERIMENT - DESCRIPTION $\ldots \ldots \bullet$

1. SPECIFIC OBJECTIVES ............... 3

2. EXPERIMENT ORGANIZATION ........ 3

3. EXPERIMENT LAYOUT . . . . . . . . . . 5

4. CROP DESCRIPTION ............... 8

5. SOIL DESCRIPTION AND PREPARATION ....... 12 ...

III. SAMPLE PROGRAM . . . . . . . . . . . 15

1. WATER SAMPLES .................. 15

2. SOIL SAMPLES . . . . . . . . 15

3. WEATHER SAMPLES AND WATERING CORRELATIONS . . • 18

4. CROP SAMPLES ............. 18

IV. CROPS TESTS, ANALYSES AND RESULTS . . . . . . 27

1. RESULTS OF ANALYSES . . . . . . . . . 27

y. CONCLUSIONS AND FOLLOW-ON ........... 40

VI. REFERENCES .......................... 42

APPENDIX A

APPENDIX B 


\section{FIGURES}

Raft River Irrigation Experiment Site locations .... 6

2 Raft River Irrigation Experiment - crop and water

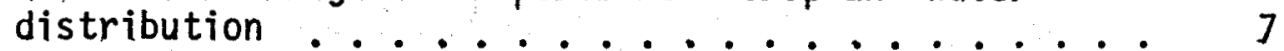

3 Crop selection guide for saline soils . . . . . . . 9

4 Irrigation system layout. . . . . . . . . . 13

$5 \quad$ Irrigation plots (Udy) July 20, 1976 . . . . . . 14

6 Growing degree day accumulations for May, June and July at Raft River Irrígation Experiment Site . . . 19

7 Growing degree day accumulations for August October at Raft River Irrigation Experiment Site . . . 20

8 Oats at time of sampling.............. 24

9 Wheat at time of sampling ........... 25

10 Typical wheat and oats samples . . . . . . . 26

11 Mature wheat on Udy plot ................... 37

12 Mature barley on Stewart plot . . . . . . . . 38

13 Typical threshed grains from experiment . . . . . . 39 
TABLES

I Chronological Events in Irrigation Experiment . . . . 4

II Vegetable, Field and Forage Crops Adapted to the Climatic Conditions in Malta-Raft River Area .... 10

III Crop Descriptions for Initial Planting ....... 11

IV Water Chemistry of Irrigation Waters ...... 16

V Analytical Datà on Soil from the Udy and Stewart Experiment Plots.............. 17

VI Evaporation - Transpiration, Precipitation and Water Application Data .................. 21

VII Averaged Maximum Wind Speeds .......... 22

VIII Crop Testing and Analyses Summary ........ 28

IX Grain Analyses Results ............ 29

X Grass, Alfalfa and Potato Analyses Results ..... 30

XI Surface Fluoride Results for Grains ......... 31

XII Grain Data Comparison - Raft River Geothermal Versus Reference Source 2.......... 33

XIII Grain Data Comparison - Raft Riyer Geothermal Versus Reference Source $3 \ldots \ldots 34$

XIV Fluoride in Crop Samples from Experimental Plots . . 36 
The Raft River Irrigation Experiment is part of a task to examine the beneficial uses of geothermal energy being performed for the Energy Research and Development Administration by the Idaho National Engineering Laboratory.

Geothermal energy projects in the planning stages today are generally predicated on using the geothermal water only for a partial extraction of its heat content, no its total fluid content. Generally, the fluid is to be returned to the geothermal reservior via reinjection. If used in non-electric applications, most plans call for physical separation of the geothermal water and the process fluid. Beneficial uses of the water such as agriculture, irrigation, aquaculture, washing and purifying operations are not given serious consideration today because of concerns over possible environmental effects either from the dissolved solids, heavy metals, or fluorides in the geothermal waters or from induced subsidence or seismicity that could possibly result if geothermal fluids are not reinjected. However, as geothermal energy usage advances, large quantities of these waters are expected to be available either in the form of discharge from power plant operations or from resources too low in temperature for power conversion. Beneficial uses of these geothermal fluids may be extremely valuable to reduce the costs of drilling reinjection wells and reinjection pumping, to provide a source of water for agriculture in water starved areas, or to reduce the cost of geothermal energy by a total energy extraction concept. Furthermore, it is argued that geothermal energy development cannot long proceed without fully understanding the potential detrimental environmental effects that might result with geothermal water contamination of soils, plants or animals.

The Raft River Beneficial Uses Task has all the foregoing considerations in mind. The task is aimed at examining many of the environmental elements of the beneficial uses of geothermal water with the exception of the reinjection question which is being examined in other ways in the Raft River Electric Project. The task utilizes actual field experiments in aquaculture, agriculture and forestry and is coupled to a measurement, sampling and interpretation program to examine crop, soil and animal history in regions subjected to long-term geothermal water exposure.

This program will provide a base of information needed for evaluation of the total use concept for geothermal fluids and needed for answers to environmental questions related to geothermal energy development. The Irrigation Experiment at Raft River, to which 
the remainder of this report is devoted, should be recognized as a contributor to the more encompassing overall beneficial uses study and environmental study efforts. 


\section{II- RAFT RIVER IRRIGATION EXPERIMENT - DESCRIPTION}

The Raft River Irrigation experiment was initiated with the 1976 growing season. Significant chronological dates for many steps in the experiment are found tabulated in Table I. The overall objectives for the experiment of contributing to understanding the beneficial uses of low salinity moderate temperature geothermal water for its fluid content and to understanding some of the environmental implications of using geothermal resources were discussed in the Introduction. More specific objectives for the experiment are given below.

\section{SPECIFIC OBJECTIVES}

1.1 To proyide a field experiment of sufficient scale for meaningful data on geothermal fuid effects on field crops.

1.2 To examine plant behavior, tolerance, yield, uptake of heavy metals, the effect of fluorides, or any abnormalities when irrigated wholly and/or partially with geothermal waters in flood and sprinkler irrigation practices.

1.3 To examine soil chemical behavior and changes when subjected to irrigation by geothermal waters over extended periods.

1.4 To accumulate a data base on material problems that might be encountered during geothermal water crop raising activities; e.g., damage to irrigation systems.

\section{EXPERIMENT ORGANIZATION}

The experiment was under the direction of INEL for ERDA with many of the required operations and services performed by INEL employees due to the experimental nature of the tasks. Two Raft River farmers with lands adjacent to the Raft River Geothermal. Project were contracted to provide the land required for the experiment and also some of the services which they could reasonably be expected to perform; e.g., initial soil tilling and seeding and follow-on tractor work. Utah State University performed major planning support activities and participated in crop sampiing and analyses through their contractual arrangement with INEL. Several other individuals and organizations such as State of Idaho Agriculture Extension Agencies provided consultation and input to the program. The organizations performing evaluations of crop samples are discussed in a later section. 


\section{TABLE I}

\section{CHRONOLOGICAL EVENTS IN IRKIGATION EXPERIMENT}

Event

Experiment approval request - Geothermal Projects to ERDA-ID

Contract agreements between ERDA-ID and Raft River Farmers (2)

Meeting at Malta, Idaho between Geothermal Project Personnel and Consultants to make crop plans and decisions

Udy plot ground preparation completed and planted to wheat, oats, and grass mixture

Stewart plot planted to barley

Irrigation equipment received on-site

Sprinkler system (Utah State University)

Flood system

(note - an installation period followed which included

establishing pumping stations, running power line, wiring pumps, etc.)

Stewart plot planted to alfalfa

Initial Watering (Raft River water on all sections)

Garden Vegetables planted

Initial geothermal watering (normal watering routine commenced)

Udy oats and wheat sprayed for Aphid infestation

Udy plot - much of lower half disced and releveled for improved flooding

Stewart plot alfalfa reseeded (alfalfa on alfalfa)

Udy plot - lower half reseeded to oats

Udy plot - lower half drilled with alfalfa (alfalfa on oats)

Crops sampled -

Oats and wheat on Udy plot

Yield samples $2^{\prime} \times 2^{\prime}$, oats, wheat and barley

Battelle Northwest Laboratory samples, neutron activation samples for all plots

Yield samples for all plots, $1 \mathrm{~m}^{2}$, oats, wheat and barley Crops harvested (crops donated to Idaho Youth Ranch)

Udy plot - Oats section on upper half disced and drilled to winter wheat

Udy plot-geothermal watering of part of winter wheat commenced Udy plot - irrigation well watering of part of winter wheat
1976

Dates

3-11

5-6 \& 5-10

5-17

5-18

$5-19 *$

5-22

5-24

6-4*

6-4 thru 6-9

$6-15$

7-6

7-31

$8-4 \& 8-5$

8-13

8-13

9-2

8-31

9-2

, 9-3

9-10

9-12

10-19

11-7

11-18 


\section{EXPERIMENT LAYOUT}

The experiment was located on about 12.5 acres of 1 and consisting of two pieces, one of 5 acres and one of 7.5 acres as shown in Figure 1. The two pieces of land are also identified as Udy and Stewart plots respectively. The smaller piece was taken from previousiy untilled land primarily covered with sagebrush and native vegetation. The larger piece had a history of previous cultivation with the principle water source being an existing irrigation we11. Figure 1 also shows the locations of Geothermal Well Sites 1 and 2. The site 2 cooling pond was used as a reseryoir for pumping purposes. Water was transferred from Well Site 1 to Well Site 2 pond to provide the geothermal water source. Details on the geothermal water are provided in a later section.

The location of the accompanying uncontrolled experiment, where established alfalfa was watered, is shown on Figure 1, occuring in a large acreage just southwest of the RRGE \#2 we11. Excess water from the Site 2 pond provided most of the irrigation needs. This operation is identified as the Darrington Experiment, and completed it's second year as of this writing. The ground had actually seen other geothermal water, for a period approaching 40 years. This water originated from a shallow artesian well about $1 / 2$ mile north of the plot, and flowed into a collection pond and, hence, into an irrigation ditch.

Both pieces of land of the controlled Irrigation Experiment were located sufficiently close to the Raft River to permit using this fresh water source as a control for comparing crop behavior between the control and the geothermal waters on parts of the land. The areas where the control water and the geothermal water were used are shown on Figure 2. Figure 2 also shows the areas where flood irrigation and sprinkler irrigation techniques were practiced. In addition, the two pieces were divided by crops into smaller pieces, and the initial crop distribution is also shown on Figure 2. More detalled information about the crops is found in the section on crop description below. It should be noted that initially no crop was planted in the garden vegetable section beyond the small portions indicated. Furtbermore, the crop distribution was al tered midway through the season, because of washing problems in the flood section on the smaller piece of land. The land was leveled differently for a better flood grade and the pasture mix in the geothermal flood and fresh water flood sections, the lower parts of the vegetable sections, and the wheat in the fresh water flood section were all replaced with an alfalfaoats cover combination crop. 


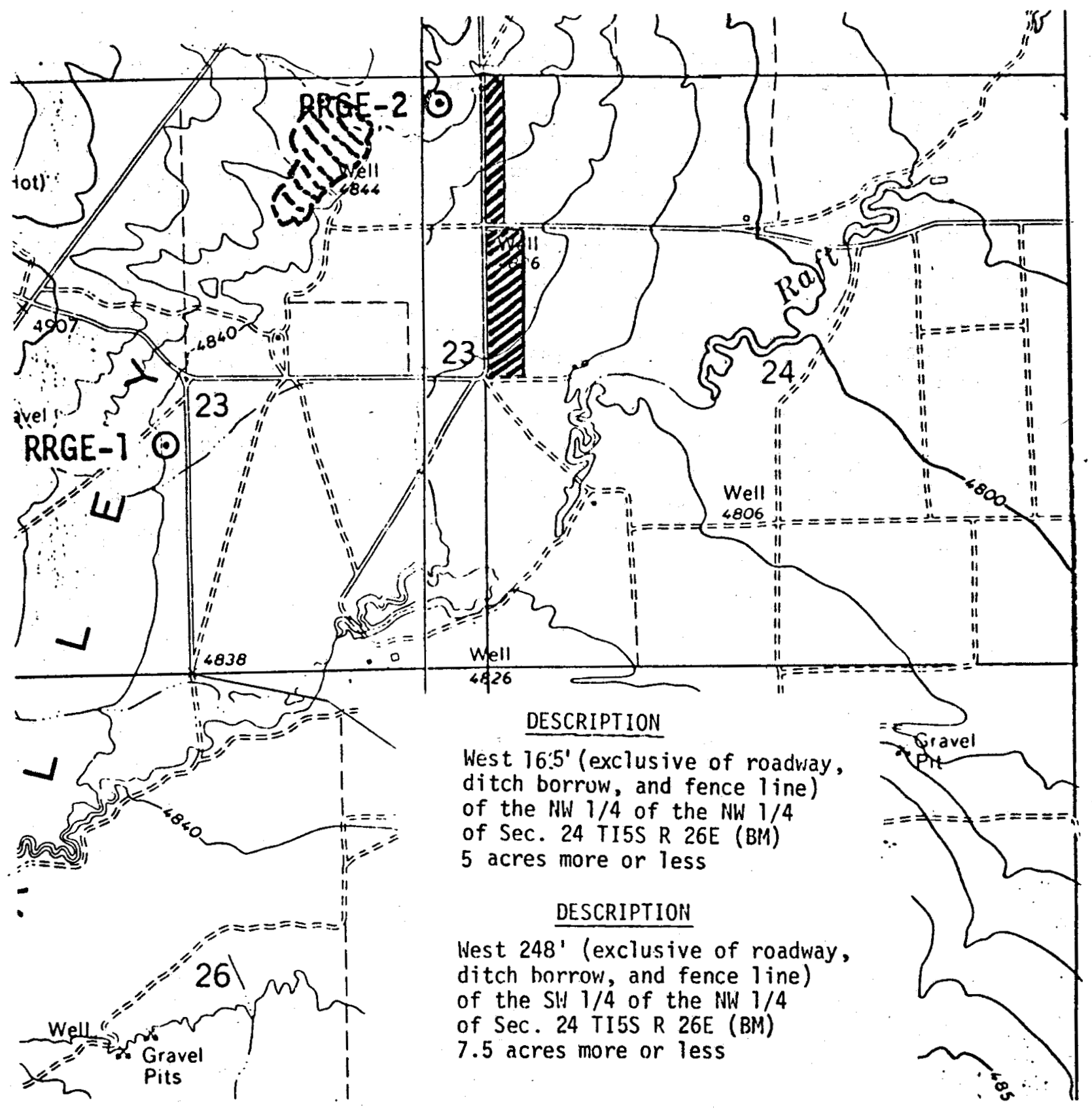

Fig. I Raft River Irrigation Experiment Site locations 


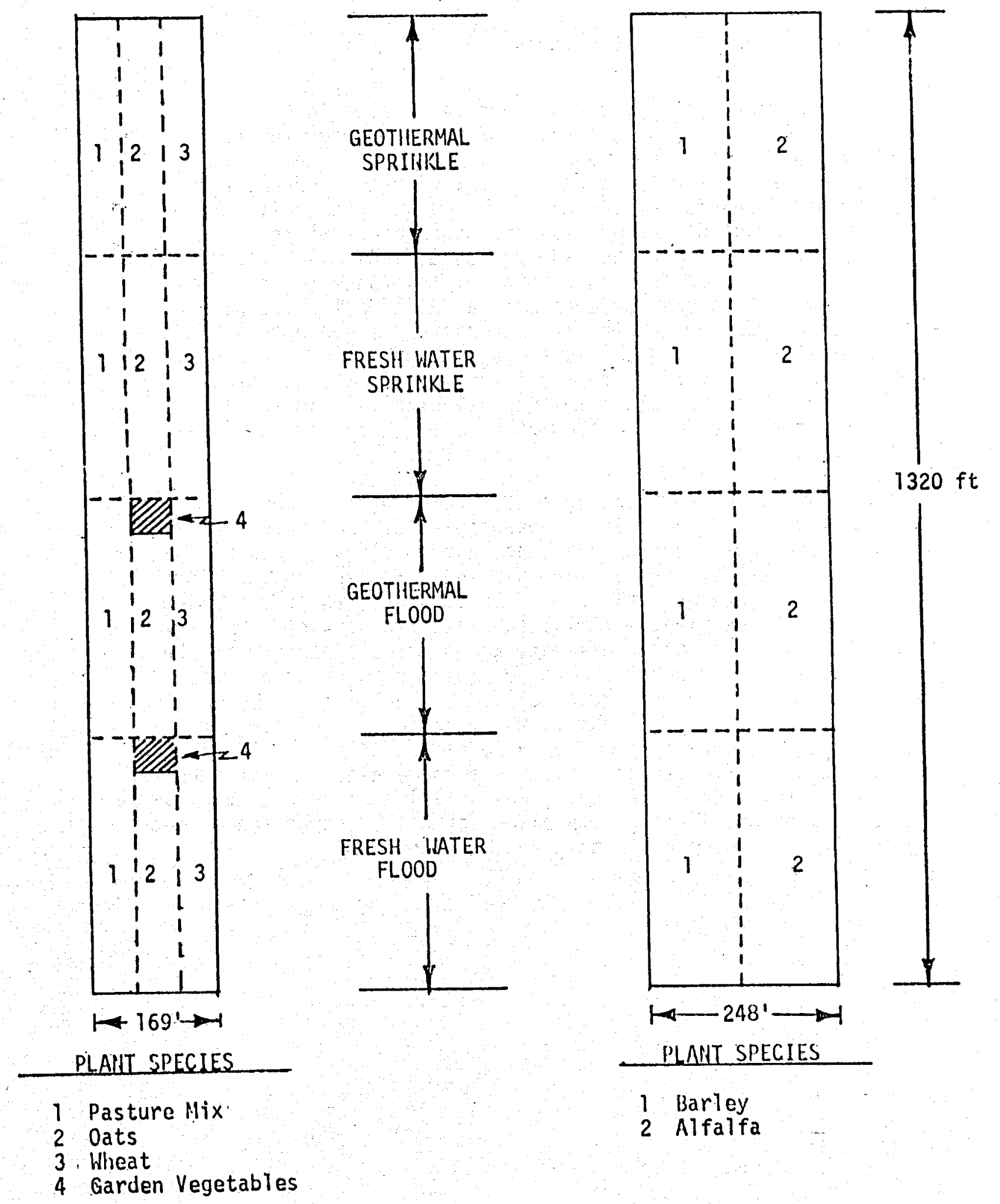

Fig. 2 Raft River irrigation experiment - crop and water distribution 


\section{CROP DESCRIPTION}

The distribution of the crops has been shown in Figure 2. The grains were chosen with a view for being adapted to the climate and typical of those grown in the Raft River area. Since the growing season for the area is short with an average frostfree period of only about 120 days, and many of the soils are saline as are many of the waters, the usual crops of the area are those adaptable to rather adverse conditions. An attempt was made to select crops with a range of tolerance to salt concentrations, but special strains such as alfalfa for use with warm water or weather conditions were not explored in this phase. of the experiment. Figure 3 is a diagram indicating the amount of salt in the soils of different textures that affects crops of different relative salt tolerance. Table II indicates the vegetable, field and forage crops adapted to the area and their relative salt tolerance.

Generally, however, the crops for this initial phase of the experiment were chosen to be representative of those grown in the area with the exception that the pasture mix was chosen to contain a variety of grasses for sampling purposes, but not for any special pasture qualities. A major concern was to determine whether or not the plant material (grains, grasses, etc.) would absorb fluorides and other elements known to be contained in the geothermal water through the roots or foliage. The effect of geothermal water on garden vegetables was considered to be of sufficient interest for inclusion in the experiment. Although vegetables are not generally grown on a large scale in the vicinity, potatos and sugar beets are found as a commercial crop in other parts of the Raft River Valley. Table III lists the grains, grasses and vegetables grown along with plant varieties, approximate seeding densities, and approximate planting dates. 


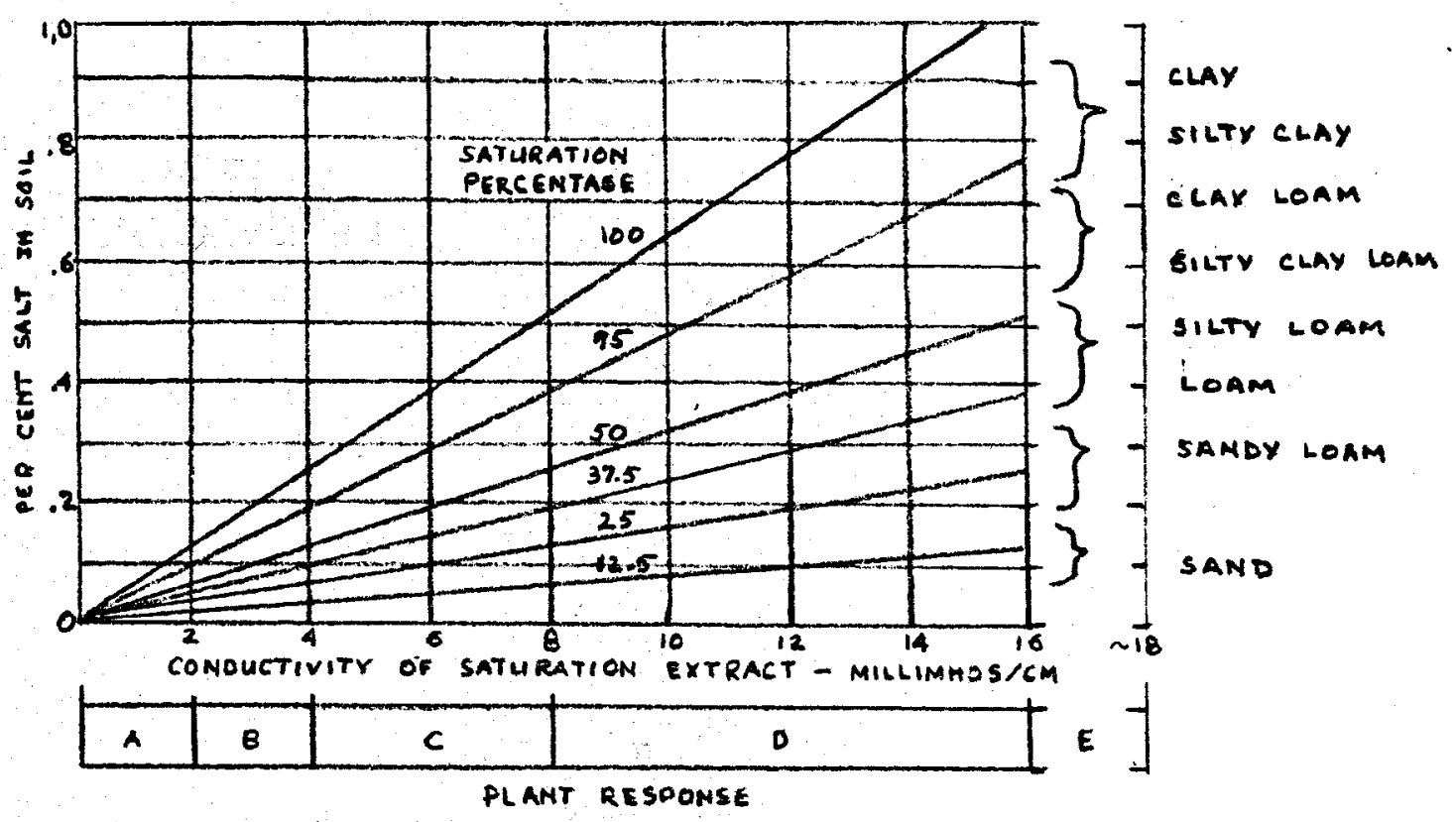

Relation of the per cent salt in the soil to the electrical conductivity of the saturation extract and to crop response in the conductivity ranges. A, salinity effects mostly negligible; $B$, yields of yery sensitive crops may be restricted; $C$, yields of many crops restricted; $D$, only tolerant crops.yield satisfactorily; $E$, only a few very tolerant crops yield satisfactorily.

Fig. 3 Crop selection guide for saline soils 


\section{TABLE II}

VEGETABLE, FIELD AND FORAGE CROPS ADAPTED TO THE CLIMATIC CONDITIONS IN MALTA-RAFT RIVER AREA. (CROPS ARE LISTED IN A DECREASING TOLERANCE TO SALINITY EXPRESSED AS MILLIMHOS/CM OF SOIL EXTRACT*)

Vegetables

Garden beets

Spinach

Tomatoes

Broccoli

Cabbage

Potatoes

Corn

Lettuce

Peppers

Onions

Carrots

Peas

Beans

Field Crops

Barley

Sugar beets

Wheat

Oats

Sunf lower

Forage Crops

Saltgriass

Ta11 wheatgrass

Canada wildrye

Barley (hay)

Sweet clover

Tall fescue

llubain clover

Miralea

Oat (hay)

Orchined grass

smooth lisome
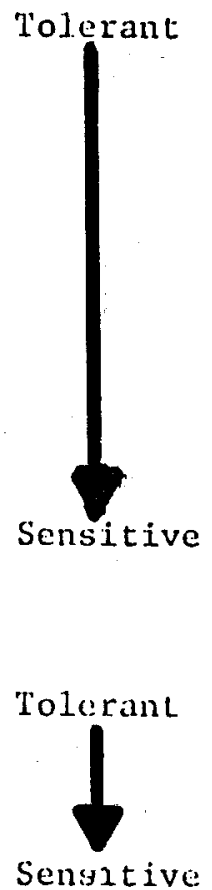

Sensative

$E C_{e}=6$

$\mathrm{IEC}_{\mathrm{e}}=4$

$B C_{e}=16$
Salinity

(mil1imhos $/ \mathrm{cm}$ )

$\mathrm{EC}_{\mathrm{e}}=12$

Tolerant $\quad \mathrm{LC}_{\mathrm{e}}=18$

$\mathrm{lic} \mathrm{c}_{\mathrm{c}}=6$

* The crops could tolerate the salinity indicated bul the yields would be expected to be reduced at least fifty percent below normal. 
TABLE III

CROP DESCRIPTIONS FOR INITIAL PLANTING †

Rate

Ibs/acre

100

100

100

$10-12$

20

(6)

(2)

(6)

(6)

A1l vegetables

per garden practices, packet instructions, etc:
Seeding

Dates

5-18

$5-18$

$5-19 *$

$5-4 *$

$5-18$

$6-15$

Vegetables

Potatoes
Beans
Lettuce
Swiss Chard
Carrot
Beet
Squash
Radish
Turnip

Northland Red Russets Improved Tendergreen Black Seeded Simpson Giant Luculius Chantenay Red Cored Ruby Queen Table King Bush Acorn Cherry Belle Purple Top White Globe

+ See also Table $I$ and text for subsequent changes

* Approximate dates 


\section{SOIL DESCRIPTION AND PREPARATION}

A soil description for the soils pertinent to the Irrigation Experiment is found attached as Appendix A. Ground, preparation for a proper seed bed was performed through the agreement with the local farmers supplying the land. Fertilizing services, including application, were obtained from a local supplier. Fertilizers were as recormended by Utah State consultants and consisted of Treble Super Phosphate or equivalent at $300 \mathrm{lbs} / \mathrm{acre}$ on all sections and Ammonia Nitrate at $200 \mathrm{Tbs} / \mathrm{acre}$ on all sections except alfalfa. A "stress" effect was inadvertently obtained in the barley on the Stewart plot when on-side or arm of the fertilizer spreader failed to spread. The resulting barley strips of different growth were duly monitored and sampled for analyses during crop sampling.

\section{IRRIGATION SYSTEM}

The irrigation system consisted of a 6-inch mainline with 3-inch lateral lines on the sprinkler sections and 6-inch gated surface pipe laterals on the flood sections. The lateral sprinkler line spacing was 50-foot, and the sprinklers were 30-foot apart. The sprinkler heads were Rainbird (\#30) with 9/64-inch nozzles placed on 3-foot risers. Each lateral line was controlable with a valve. Each gated surface pipe line initiated with a valve at the mainline and a 55-gallon riser barrel for pressure drop. One gated surface line was located at the top end of each of the four flood irrigated sections. The gates were on 30 -inch centers.

The furthest pumping distance for the 6-inch mainline was about 5/8-mile for the river water. A Berkley $25 \mathrm{HP}$ centrifugal pump was used at the river. The pump used at the geothermal pond was a $10 \mathrm{HP}$ centrifugal during most of the watering. Either pump was intended to produce 100 foot of head (44 psi) at the sprinkler nozzles. The resulting water application rate was about 0.25 -inch of water per hour. The quantities of water applied to the crops are discussed in Section 3.3 as part of the weather sampling and watering correlations. The entire set system with the exception of some of the 6-inch mainline, the gated surface line components and the $10 \mathrm{HP}$ pump was supplied on loan to INEL by Utah State University through their Agriculture and Engineering Department. Typical layout diagrams of the irrigation system are shown in Figure 4. Figure 5 shows part of the irrigation system and crops on the Udy plot early in the experiment. The 6-inch mainline is visible on the left. Several lateral lines with risers are shown. The pasture mix is on the left and oats and wheat on right. Picture was taken on July 20, 1976. 
SPRINKLER SECTION

(Typical)

To Geothermal Water

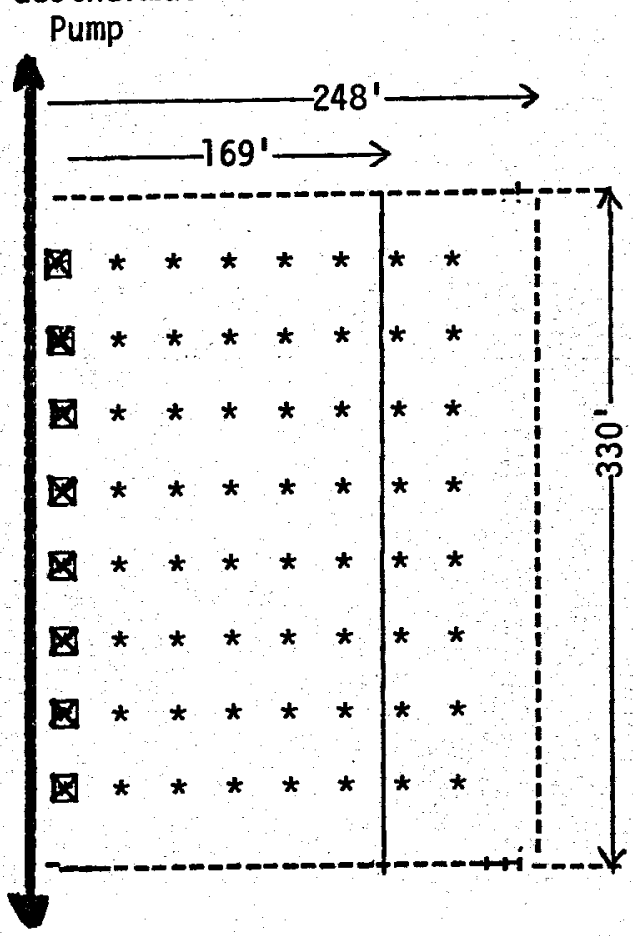

To River Water

Pump

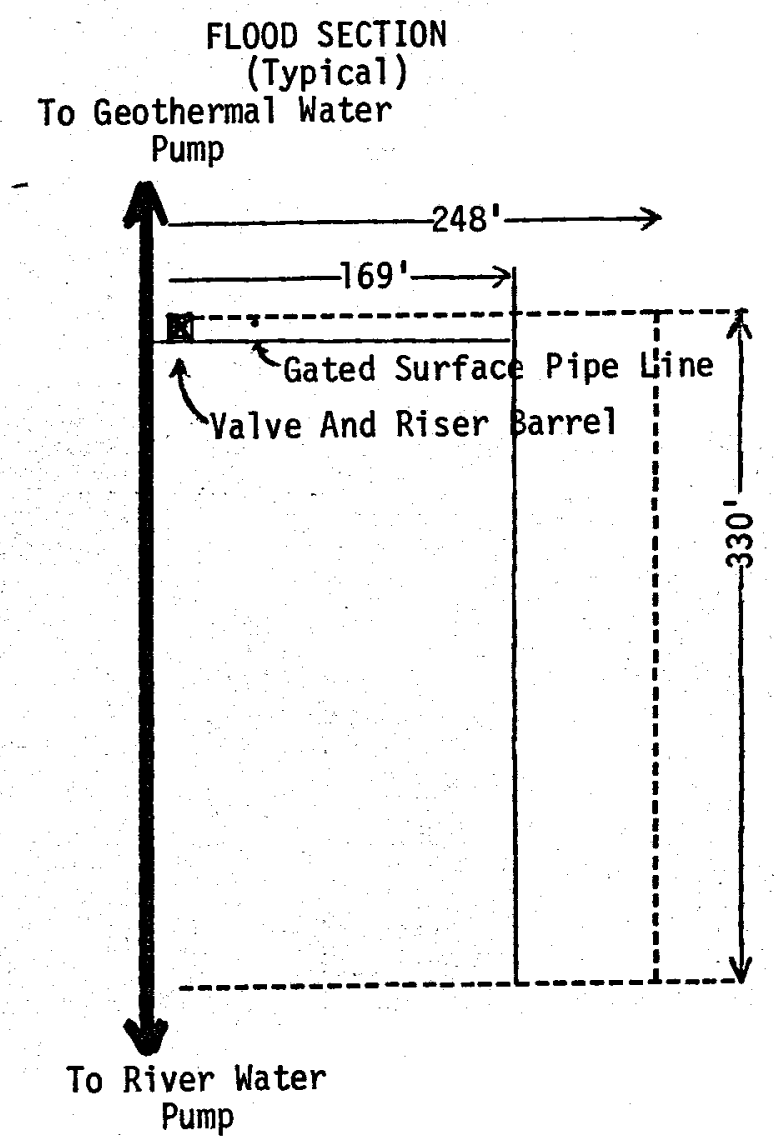

* Sprinkler Heads

Valves.

Fig. 4 Irrigation system layout 


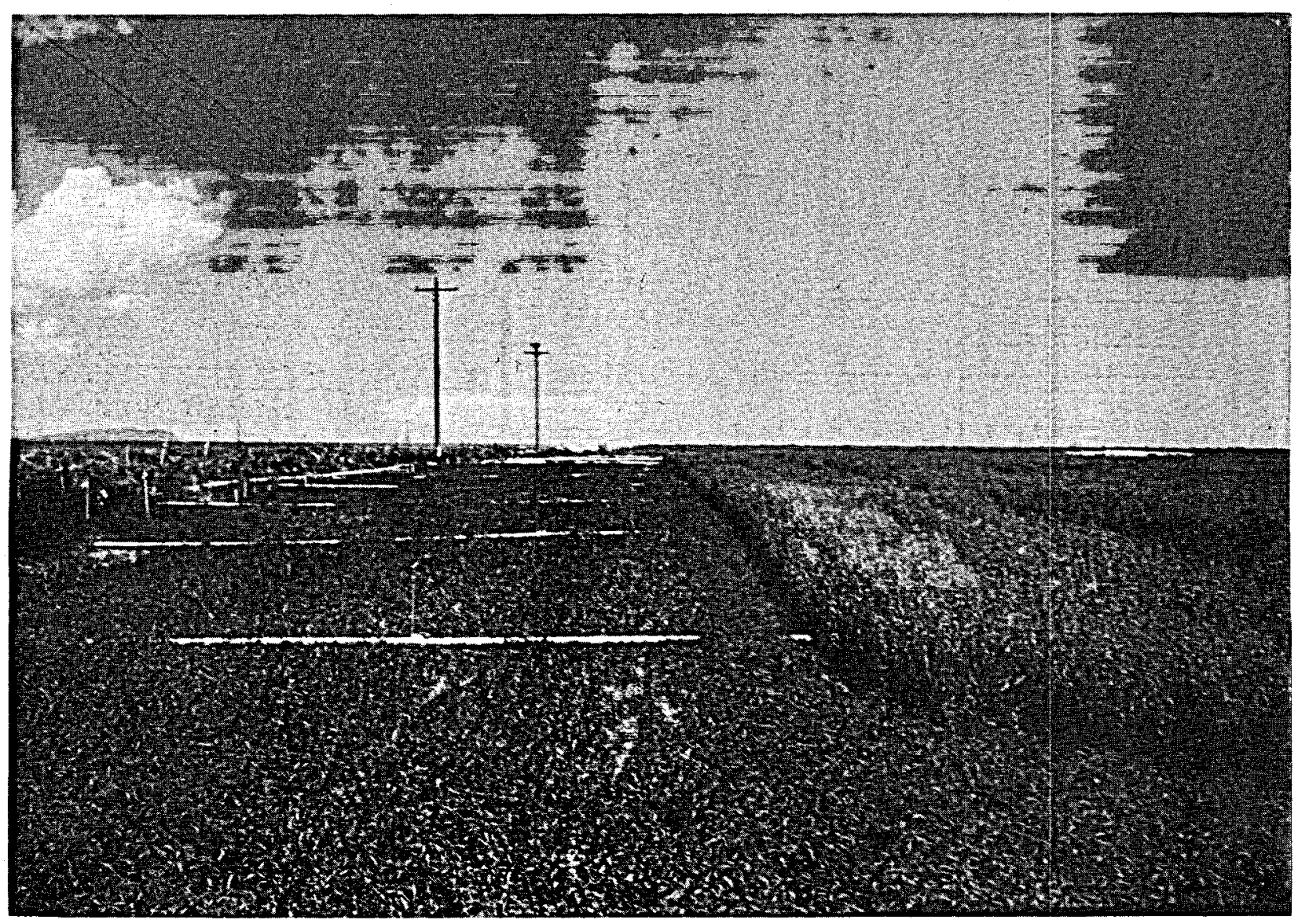

Fig. 5 Irrigation plots (Udy) JuTy 20, 1976 
III. SAMPLE PROGRAM

An extensive sampling program was pursued at Raft River for the Irrigation Experiment and for environmental objectives. Soil, water, weather and crop samples were taken as discussed separately below. The soil and water samples will be used not only for this phase of the Irrigation Experiment, but also as baseline data for follow-on phases and environmental studies.

\section{WATER SAMPLES}

Water from two of the geothermal wells, the Raft River, and irrigation wells in the area was analyzed periodically during irrigation. Twenty two irrigation wells and four points on the Raft River have been sampled by the State at the beginning and end of each irrigation season. These results were used to characterize the water used on the control plots. The geothermal water used for irrigation was sampled weekly at the RRGE-2 pond and at the surge tank on the flood lines. These samples were divided into: (1) a filtered, nontreated sample for anions, an unfiltered, nontreated sample for carbonates, etc., and (3) a filtered, acidified sample for the metallic ions. Duplicate samples were made and stored for future reference. All samples except those acidified were diluted 1 to 2. Enough samples from the Raft River water were taken to adequately characterize the chemistry of the river water. Results from the water analyses are shown in Table IV. The geothermal water temperature of $36^{\circ} \mathrm{C}\left(\sim 97^{\circ} \mathrm{F}\right)$ was consistent at the RRGE-2 pond and at the surge tanks during irrigation.

Appendix B contains a discussion of water quality classes, a diagram for determining the water quality rating, along with a discussion of the hazards associated with low quality water. In addition to the irrigation hazards described in Appendix $B$, some problems might develop in the distribution of geothermal water in the form of corrosion or depositions of calcium carbonate, etc. These problems are often enhanced by soil-to-pipe interchange. The problem was largely countered by slightly elevating the geothermal distribution lines (system placed on about 6-inch diameter blocks), and no significant corrosion effect has been noted to date.

\section{SOIL SAMPLES}

Soil samples were taken for chemical analyses and will serve as a reference to measure the changes that might be attributed to the quality of the water used for irrigation. A soil survey for the area of the Irrigation Experiment was also completed. The results of these actiyities in connection with this experiment and the overall environmental study are found compiled in Appendix A, Soil Description." A summary of analytical data for the two irrigation plots is given in Table $V$. 
TABLE IV

WATER CHEMISTRY OF IRRIGATION WATERS*

Geothermal

Season Ave.

$T\left({ }^{\circ} \mathrm{C}\right)$

36

$\mathrm{pH}$

TDS

B

$\mathrm{Ca}$

$\mathrm{Fe}$

K

Li

$\mathrm{Mg}$

$\mathrm{Na}$

$\mathrm{Ni}$

$P$

Si

$\mathrm{SiO}_{2}$

$\mathrm{Sr}$

$\mathrm{Cl}^{-}$

$\mathrm{CO}_{3}=$

$\mathrm{F}^{-}$

$\mathrm{HCO}_{3}{ }^{-}$

$\mathrm{SO}_{4}=$
8.3

1850

0.19

53

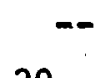

39

1.6

0.57

564

0.01

$<0.1$

70

180

1.4

936

14.2

9.4

26.8

0.1

--
Raft Riyer

Spring

$1650-2038 \quad 370$

$0.16-<1.0$

$<0.1$

$30-45$

$480-796$

$<.01-.016$

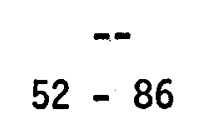

$162-200$

$0.9-1.73$

$809-1338$

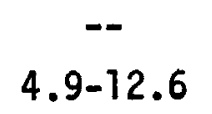

234

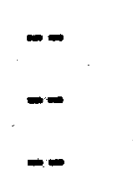

17

8.1

0.07

60

5.6

$<0.1$

12.8

45

5.2

33

$-$

62

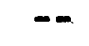

0.44

17

8.2

760

0.12

104

0.20

8.6

0.05

25

99

--

0.01

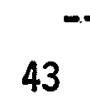

204

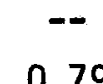

0.79

261

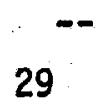

78
Average for

Irrigaticn

Wells **

26

7.7

1000

0.1

97

$<0.1$

16.5

1.2

10

536

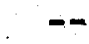

0.01

58

895

3.6

169

74

* Values in ppm unless otherwise noted.

**Average of the three irrigation wells within $1 / 2$ mile of the plots. If other irrigation wells in the yalley were included, the ayerage TDS would be much lower. 
TABLE $Y$

ANALYTICAL DATA ON SOIL FROM THE UDY AND STEWART EXPERIMENT PLOTS*

\begin{tabular}{|c|c|c|c|c|c|c|c|c|}
\hline Sample & $\begin{array}{l}\text { Depth of } \\
\text { Sample, in. }\end{array}$ & $\mathrm{pH}$ & $\begin{array}{c}\operatorname{mmhos}_{\mathrm{EC}} / \mathrm{cm} \\
\mathrm{e}\end{array}$ & CEC & $\begin{array}{l}\mathrm{me} / 100 \mathrm{~g} \\
\mathrm{H}_{2} \mathrm{O} \mathrm{Na}\end{array}$ & Sat. \% & $\begin{array}{l}\mathrm{me} / 100 \mathrm{~g} \\
\text { Ext. Na. }\end{array}$ & $\begin{array}{c}\text { Exchangeable } \\
\text { Sodium \% }\end{array}$ \\
\hline Udy & $0-6$ & 8.2 & 1.5 & 18.9 & .4 & 39.7 & 2.2 & 9.5 \\
\hline Stewart & $0-6$ & 8.0 & 2.9 & 25.0 & 1.2 & 57.8 & 5.4 & 16.9 \\
\hline
\end{tabular}

*Bulk soil samples were taken May 17, 1976, from throughout each of the areas. Subsamples were then taken of each for analysis. These data should serve as reference information obtained prior to any treatments.

ECe - specific electrical conductance

CEC - cation exchange capacity (a measure of the quiaity of the soil; CEC = me/100 gms of sample)

me - mili equivalents ( $\mathrm{mi} \times$ Normality $=\mathrm{me} ; \mathrm{ppm}(\mathrm{mg} / \mathrm{l}) \div$ Form Wt. $=\mathrm{me} / \mathrm{l}$ )

$\mathrm{H}_{2} \mathrm{ONa}$ - water soluble sodium

Sat. \% - saturation percentage

Ext. $\mathrm{Na}$ - extractable sodium 


\section{WEATHER SAMPLING AND WATERING CORRELATIONS}

Weather data was collected from an on-site weather station and supplemented with data from the Malta and Strevel1 U.S. Department of Commerce National Oceanic and Atmosphere Administration Weather Stations.

A growing degree day accumulation is displayed in Figure 6 and 7 for the months of interest. The growing degree day interpretation is found in documents such as Reference 1 and relate expected plant growth with air temperature. The white band, representing temperature between $40^{\circ}-77^{\circ} \mathrm{F}$, is that temperature span in which optimum plant growth occurs. Daily temperature minimums and maximums are averaged and the minimum plant growth temperature subtracted to compute the daily growth units called growing degree days (GDD). The normal growing degree days for the Rupert, Idaho area between May 15 and September 12 is $2785 \mathrm{GDD}$. The $1976 \mathrm{Malta}$ area conditions yielded a total of $2495 \mathrm{GDD}$. slightly shy of normal growing conditions.

The evaporation-transpiration data derived from the National Oceanic and Atmospheric Administration's Idaho Climatological Data, Volume 79 Number 5-9 for the months May-September is given in Table $y_{I}$ along with precipitation. The difference is a measure of the moisture required to be made up by irrigation. The estimated amount of irrigation water applied to the crops for some of the months of interest is included in the table. The range shown reflects that some crop sections received as little as the smallest number of inches of water given while others received the larger quantity.

Maximum wind speeds and the number of days per month when such maximums were recorded are shown in Table VII. The table data is for the Strevell station which has wind behavior much the same as the geothermal site. Also shown are data for Moscow and Aberdeen stations. Clearly, the geothermal site is an area of significant wind behayior although not usually of the very high velocities during the growing season.

\section{CROP SAMPLES}

A large number of crop samples were taken for use with the various analytical techniques. The crop sampling is summarized as follows:

Grains - Each grain plot was sampled for activation analyses in up to four locations with soil, roots, stems and heads of grain taken separately at each location. The resulting 150 or more samples were each sufficiently large for subdividing. Each grain plot had one or more large sample of stalks of grain removed for chemical analyses. Each grain plot also had $2 \mathrm{ft} . \times 2 \mathrm{ft}$. and $1 \mathrm{~m}^{2}$ samples removed for yield analyses. The barley section had additional samples removed to evaluate the "stress" effect of fertilized versus unfertilized strips. 


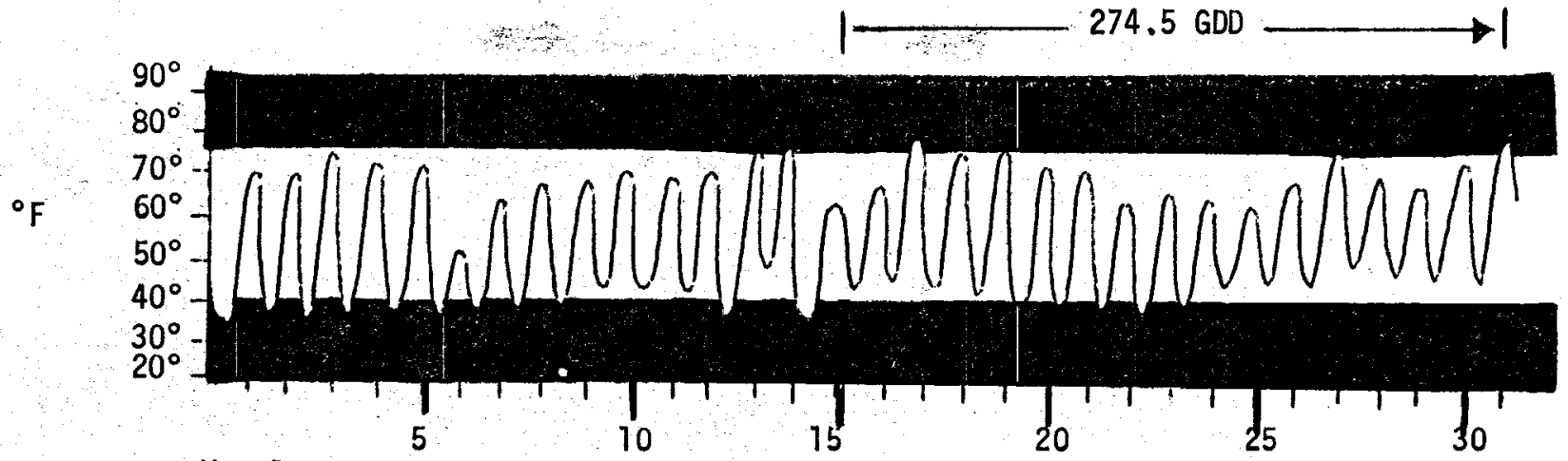

May 1976

TOTAL GROWING DEGREE DAYS $=478.5$

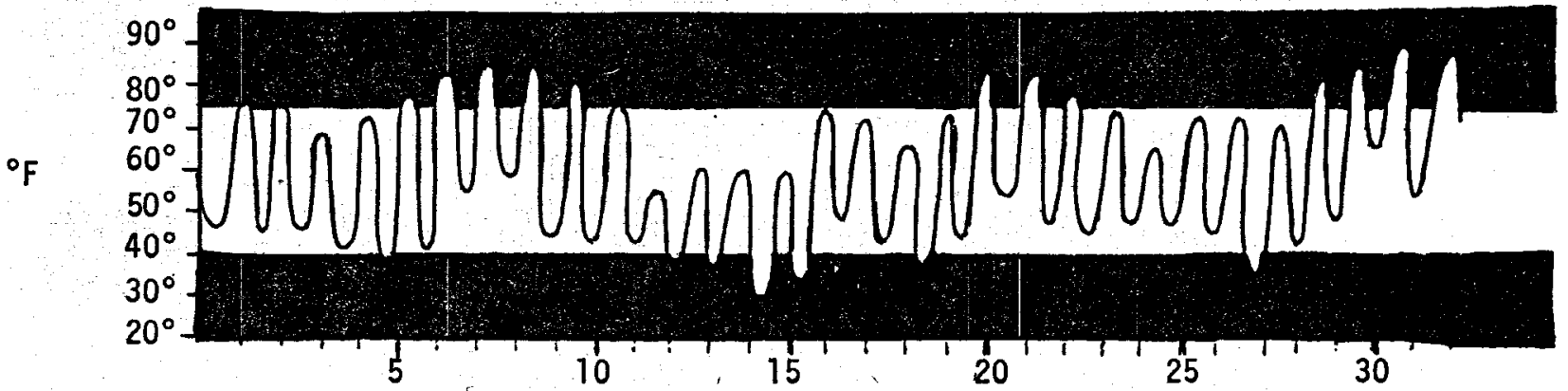

June 1976

TOTAL GROWING DEGREE DAYS $=555$

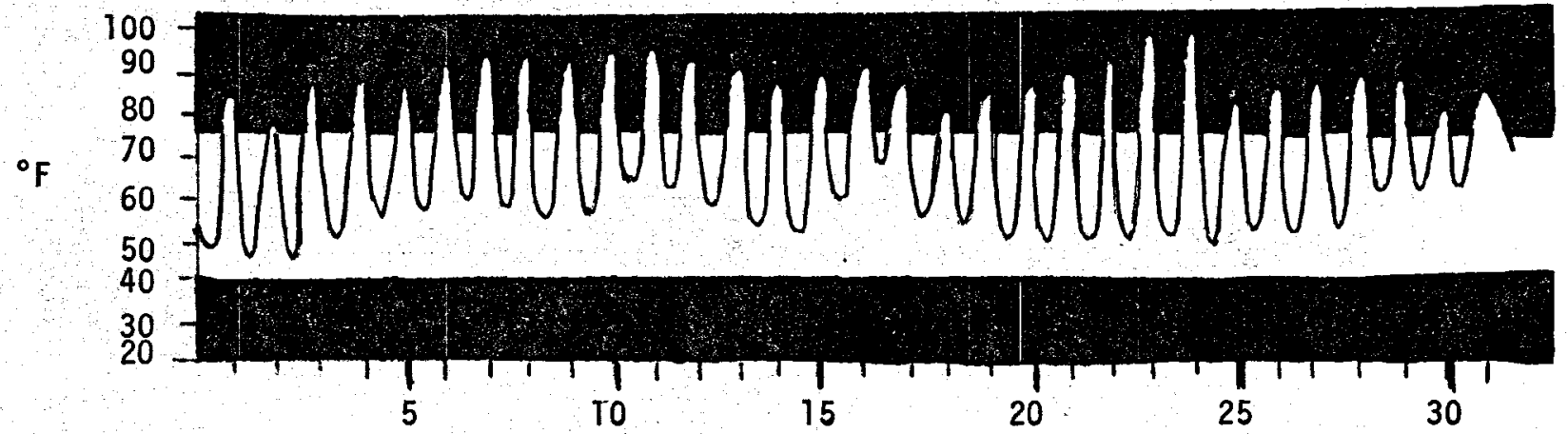

July 1976

TOTAL GROWING DEGREE DAYS $=792.5$

Fig. 6 Growing degree day accumulations for May, June, and July at Raft River Irrigation Experiment Site 


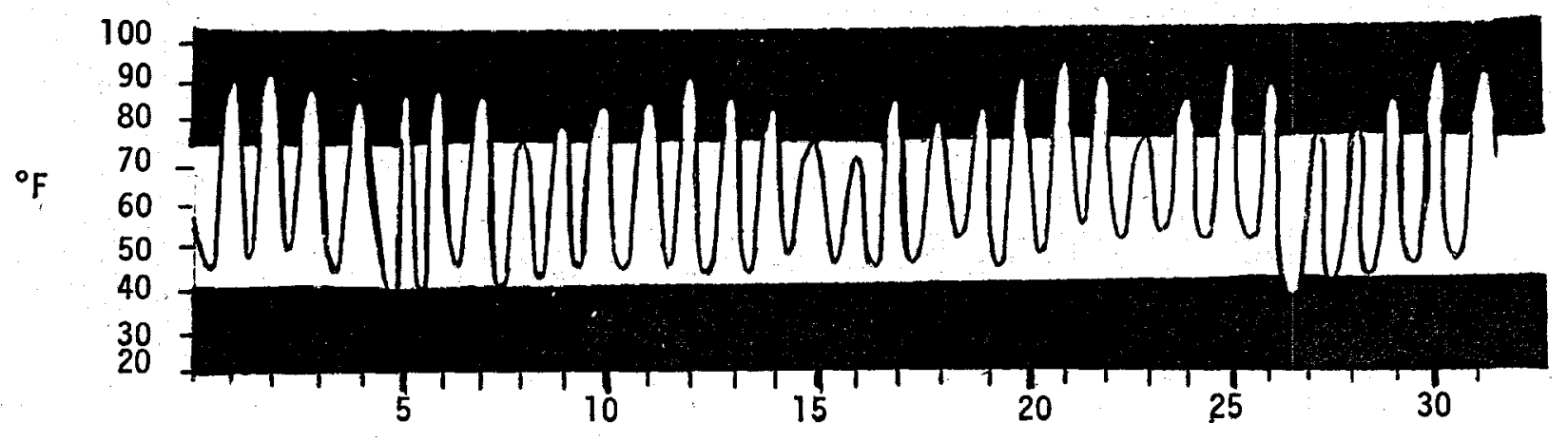

August 1976

TOTAL GROWING DEGREE DAYS $=649.5$

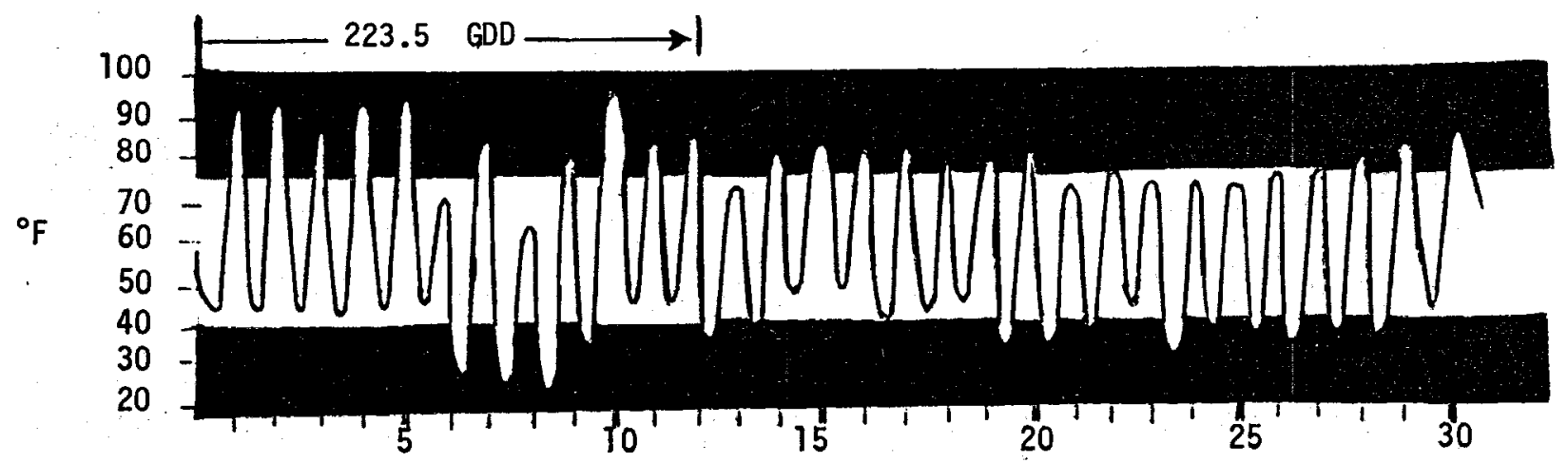

September 1976

TOTAL GROWING DEGREE DAYS $=556.5$

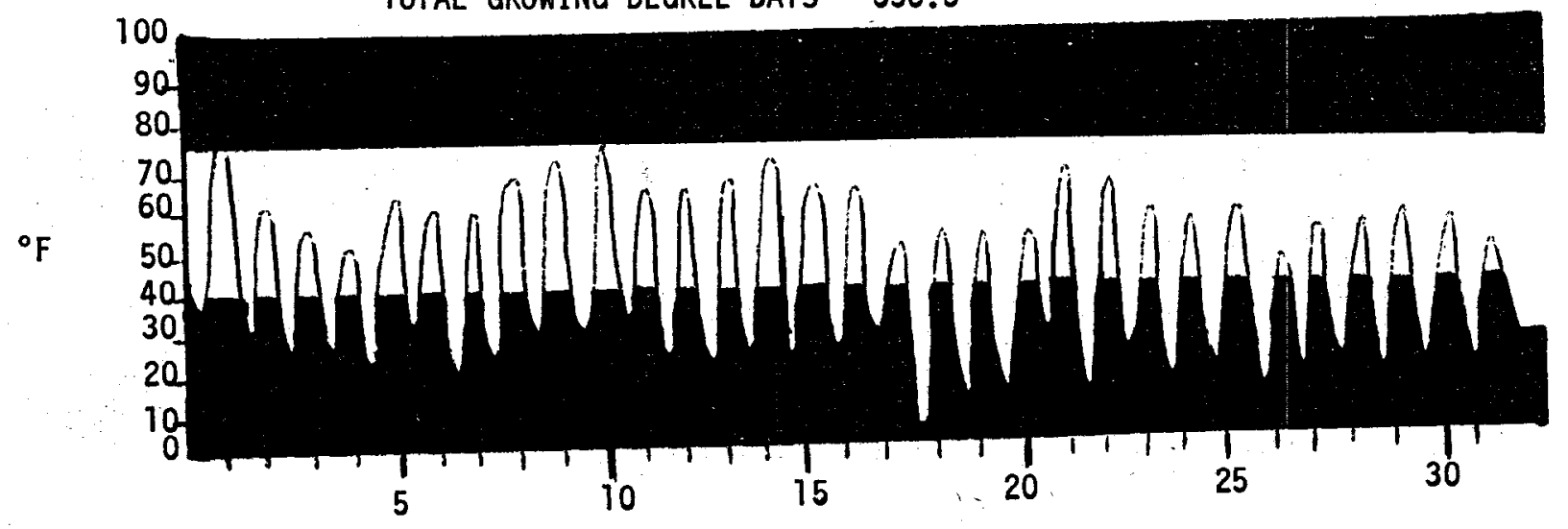

October 1976

TOTAL GROWING DEGREE DAYS $=316$

Fig. 7 Growing degree day accumulations for August - October at Raft River Irrigation Experiment Site 


$$
\begin{aligned}
& \text { TABLE VI } \\
& \text { EVAPORATION - TRANSPIRATION, PRECIPITATION AND } \\
& \text { WATER APPLICATION DATA (ALL DATA IN INCHES OF } \mathrm{H}_{2} O \text { ) }
\end{aligned}
$$

Month

May

June

JuTy

August

September
E-T Potential*

6.72

7.61

9.14

7.76

5.90
Precipitation**

0.28

(0.15 after May 15)

0.35

0.27

0.46

0.26

(0.20 by September 12)
Estimated Water*** Application

none

$5.8-12.5$

$1.8-7.9$

$0-3$

* $E$ = eyaporation from soil, $\mathrm{T}$ = transpiration from plant; the combination is the maximum potential for molsture loss from a well watered crop is usually based on alfalfa rates; from National Oceanic and Atmospheric Administration's Idaho Climatological Data, Yolume 79 - Number 5-9.

** From weather data as discussed in text under Section 3.3 .

*** The indicated range reflects that some sections received the smaller application for the month and others the larger. 
TABLE VII

AVERAGED MAXIMUM WIND SPEEDS,

(Streyel1 Data)

Wind Speed

Range (MPH)

$0-2$

$2-4$

$-4-6$

$6-8$

$8-10$

$10-12$

$12-14$

$14-16$

$>16$

Average Max.

Speed (MPH)

Recorded Days /

Month

Moscow

Average

(U of I, MPH)

Aberdeen

Average (MPH)
Number of days having speeds within range

May June July Aug. Sept Oct.

$\begin{array}{lllllll}3 & & 0 & 1 & 7 & 5 & 5 \\ 1 & 2 & 4 & 4 & 5 & 2 \\ 2 & 5 & 1 & 4 & 3 & 2 \\ 5 & 7 & 5 & 4 & 3 & 4 \\ 7 & 5 & 3 & 1 & 1 & 2 \\ 4 & 5 & 4 & 4 & 1 & 2 \\ 6 & 3 & 4 & 1 & 0 & 8 \\ 2 & 1 & 0 & 0 & 1 & 3 \\ 1 & 1 & 0 & 1 & 1 & 0\end{array}$

9.2

$8.7 \quad 8.0$

5.5

$5.4 \quad 8.4$

37

$29 \quad 22$

26

$20 \cdot 28$

$\begin{array}{llllll}3.2 & 2.5 & 1.9 & 1.7 & 2.1 & 1.9\end{array}$

$\begin{array}{llllll}5.2 & 5.3 & 3.9 & 3.9 & 3.4 & 3.3\end{array}$ 
Grasses - Each grass plot had samples removed for both activation and chemical analyses.

Alfalfa - Each alfalfa section had samples similar to the grasses removed, and for the same purpose.

Vegetables - Samples of the potatos were removed for activation and chemical analyses.

All sampling was conducted in a manner to avoid contamination by the sampling process; i.e., stainless steel scissors, clean plastic containers or bags (plastic and paper) were used and contact with hands, etc. was avoided. Figures 8,9 , and 10 show the crop at the time of sampling. 


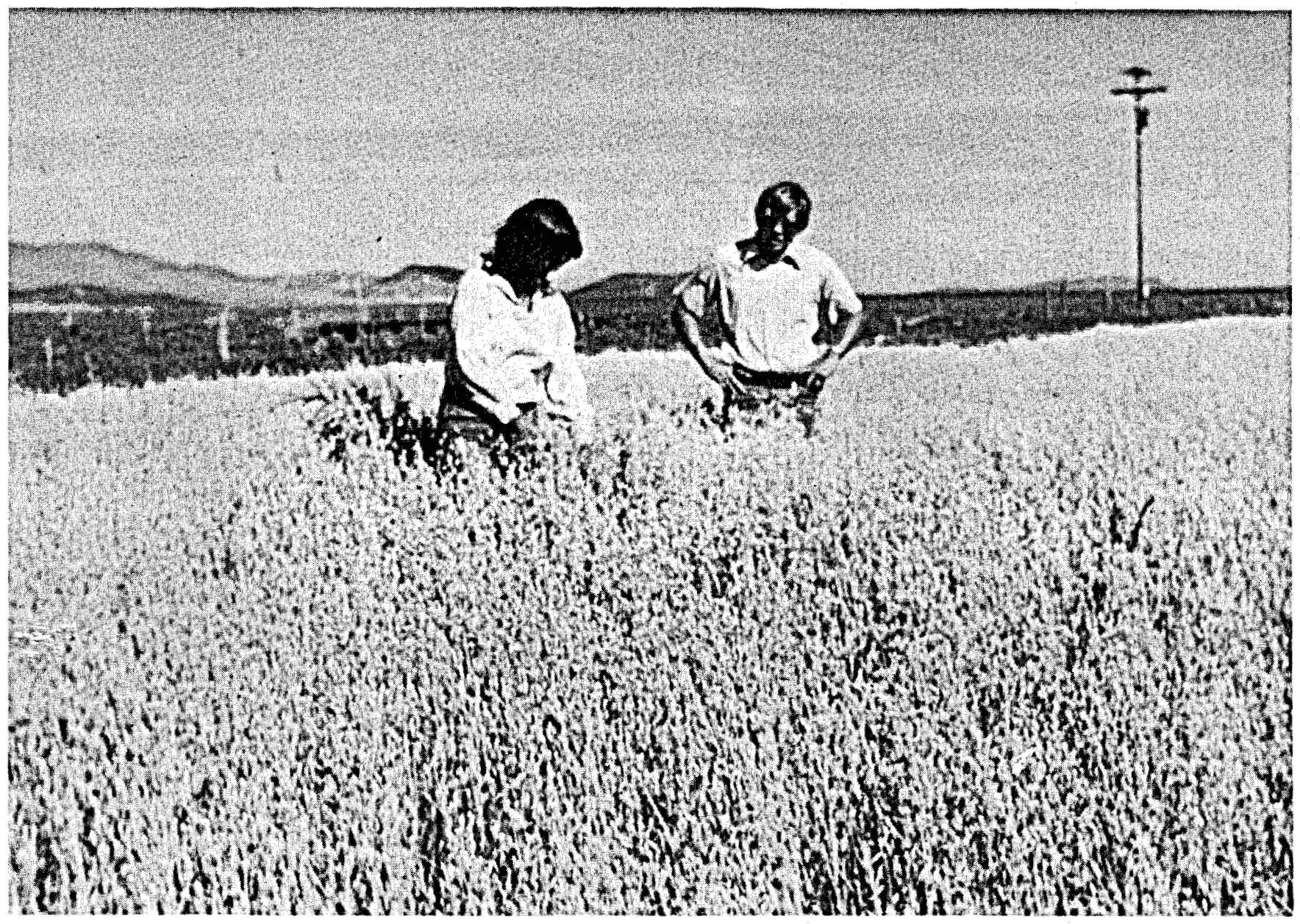

Fig. 8 0ats at time of sampling 


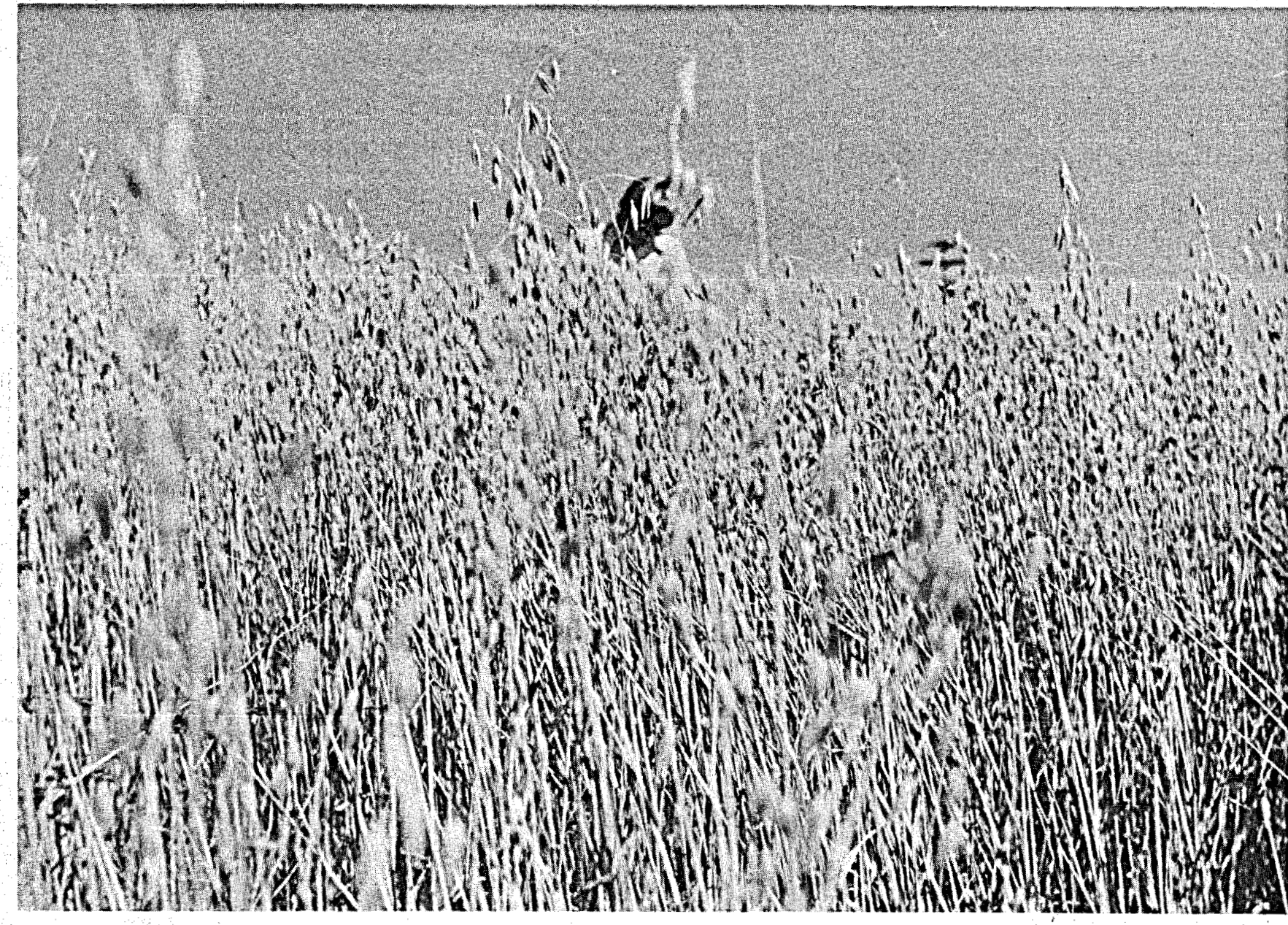

Fig. 9 Wheat at time of sampling 


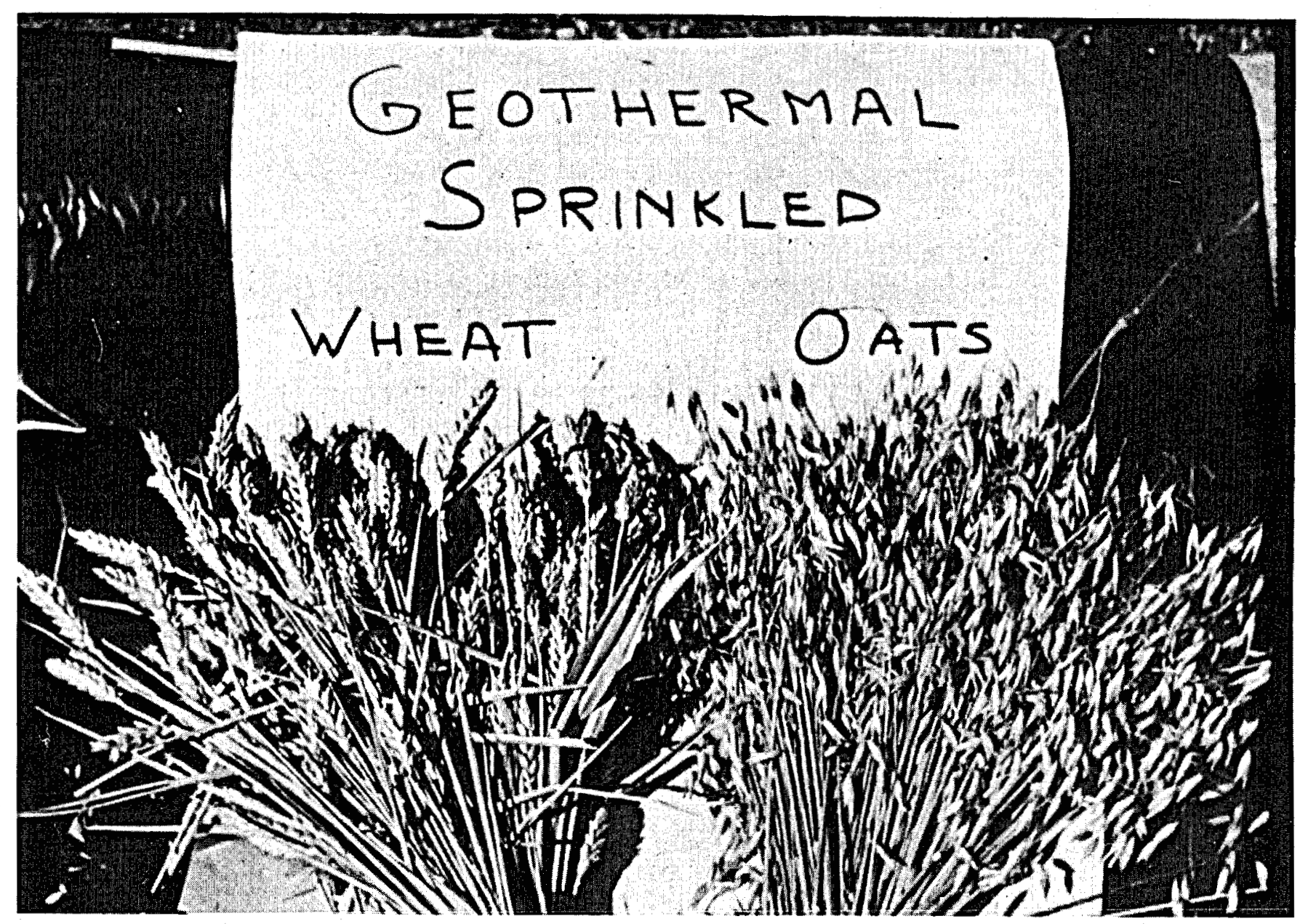

Fig. 10 Typical wheat and oats samples 


\section{CROP TESTS, ANALYSES AND RESULTS}

A diversity of organizations are performing tests and analyses directed at crop, water, and soil characteristics for this experiment. The organizations, types of tests and/or analyses, and primary information being produced are summarized in Table VIII. It should be noted that many results from the tests and analyses are incomplete and not included in this report. However, some results are discussed below and all results are expected to be accumulated in a following data report which is tentatively scheduled for release 6-30-77.

\section{RESULTS OF ANALYSES}

Tables IX and $X$ below are compilations of part of the results from sample analyses. Table 9 shows the results from Agricul ture Testing and Consultants, Inc. for the grain, and Table 10 for alfalfa, grasses and potatoes. Of interest in these tables is, that for a particular crop species, no significant differences are seen between fresh water and geothermal water irrigation. The results in these tables report constituents on a total basis; i.e., the sample is ground, dried and analyzed. A different analyses involyes determining sample surface constituents. Preliminary results from Allied Chemical for surface fluoride analyses of grains are shown in Table XI. The surface fluoride was determined by mixing the samples for one hour with a solution that was 0.5 molar sodium citrate, one molar $\mathrm{NaCl}$ and 0.05 molar triethanolamine adjusted to $\mathrm{pH}$ of 7.0 . This strong complexing solution for cations frees fluoride from all the cations and also dissolves calcium and magnesium fluoride. The fluorides were measured using a specific ion electrode and compared to standards. As an additional check on the analyses, a standard addition procedure was applied to all samples. The standard addition method verified the fluoride values obtained by direct measurement.

The results in Table XI clearly indicate that surface fluoride is much more pronounced in the geothermal sprinkled crops, an effect that disappears with geothermal flooded crops. In the case of geothermal flooded crops, the results are much the same as those where fresh water was used. But these results are very prel iminary and will need additonal investigation in follow-on phases of this experiment.

Some different comparisons are shown in Tables XII and XIII. In Table 12, the Raft River results for geothermal water crops are compared to compilations found in Technology of Cereals, authored by N. L. Kent. 2 Since the moisture basis was not the same for the two analyses (11- 15\% moisture content for Reference 1 data versus about $1 \%$ for Raft River), the results may be misleading. Nevertheless, for example, certain significant difference in crude fibers, ash, fluorine and lead are observed. 
TABLE VIII

CROP TESTING AND ANALYSES SUMMARY

\section{Name of Organization}

Agriculture Testing and Consultants, Inc. (Twin Falls, Idaho)

Allied Chemical Corporation (INEL - Idaho)

EG\&G Idaho, Inc. (ATR Experiments)

\section{University of Utah}

N (TRIGR Test Reactor)

Utah State University

(Agriculture and Irrigation Engineering)

Engineering Incorporated (Idaho Fal is, Idaho)

Battelle Northwest Lab, * (Richland, Washington)

\section{Type of Tests or Analyses}

Feed and Plant Tissue

Mineral

Fluoride

Fluoride

Water

Neutron Activation

Neutron Activation

Soil

Yield Determiniations

Fluoride

Water

Neutron Activation

\section{Primary Areas of Information}

Complete Feed Analyses, Selected Mineral Concentrations, and Fluorine Concentrations in Grains, Grasses, Alfalfa and Potatoes

Surface and Total Fluorine for Grains, Grasses, Alfalfa and Potatos Water Analyses for Dissolved Solids, Fluoride, Mineral Constituents, Etc.

Primarily Mineral Constituents and Concentrations (Grain Oriented Includes Soil, Root, Stem, and Grain Samples for Each Sampling Location)

Much the Same as at EG\&G above but with Fewer Samples. Some Development of Experimental Techniques. Some Emphas is on Fluoride.

Soil Constituents, Quality, Type, Alternations, Etc. Grain Yields Plant Fluoride (aifalfa)

Water Analysis Similar to Allied Chemical

Heavy Metal Concentrations in Grains.

* Grain samples provided to BNL at no cost in exchange for copies of analytical results. 
TABLE IX

GRAIN ANALYSES RESULTS*

(FROM AGRICULTURE TESTING AND CONSULTANTS, INC.)

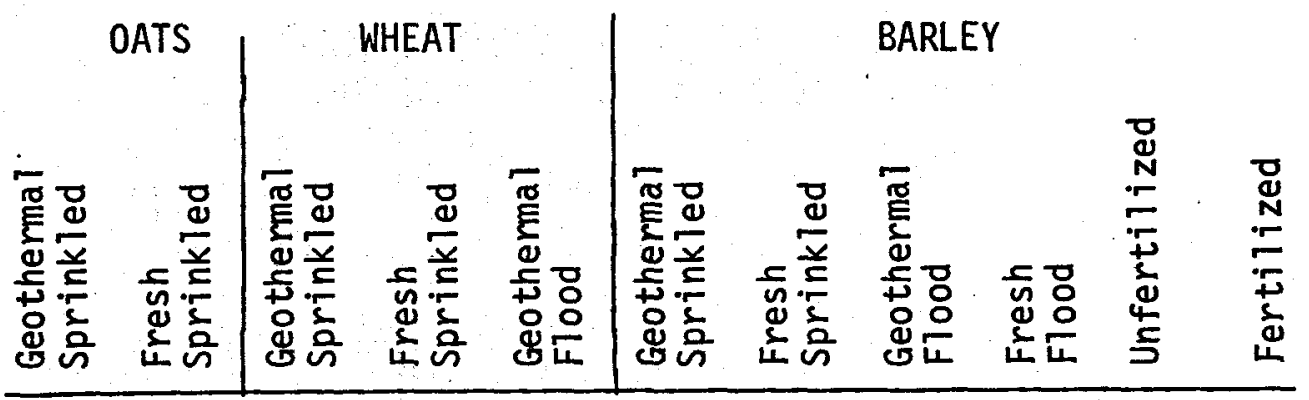

\begin{tabular}{|c|c|c|c|c|c|c|c|c|c|c|c|}
\hline $\begin{array}{l}\text { Crude Prote } \\
\text { Crude Fat } \\
\text { Crude Fiber } \\
\text { Ash } \\
\text { NFE } \\
\text { TDN } \\
\text { Dry Matter }\end{array}$ & 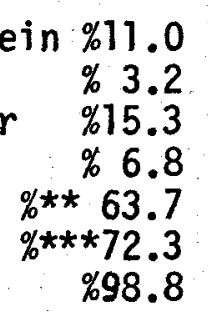 & $\begin{array}{r}8.7 \\
3.1 \\
17.9 \\
7.8 \\
62.5 \\
70.4 \\
98.7\end{array}$ & $\begin{array}{r}8.7 \\
1.1 \\
10.0 \\
5.1 \\
75.1 \\
84.7 \\
99.6\end{array}$ & $\begin{array}{r}8.4 \\
1.2 \\
10.6 \\
4.4 \\
75.4 \\
85.3 \\
98.7\end{array}$ & $\begin{array}{r}9.4 \\
1.3 \\
15.0 \\
6.6 \\
67.7 \\
82.4 \\
99.3\end{array}$ & $\begin{array}{r}9.9 \\
1.4 \\
10.6 \\
5.5 \\
72.6 \\
83.1 \\
98.9\end{array}$ & $\begin{array}{r}10.0 \\
1.3 \\
10.7 \\
6.3 \\
71.7 \\
82.2 \\
99.1\end{array}$ & $\begin{array}{r}9.2 \\
1.3 \\
12.0 \\
8.1 \\
69.4 \\
80.2 \\
98.7\end{array}$ & $\begin{array}{r}9.9 \\
1.1 \\
12.0 \\
7.2 \\
69.8 \\
80.7 \\
98.8\end{array}$ & $\begin{array}{r}9.1 \\
1.3 \\
10.9 \\
6.1 \\
72.7 \\
82.5 \\
94.4\end{array}$ & $\begin{array}{r}9.8 \\
1.2 \\
12.5 \\
9.2 \\
67.3 \\
80.0 \\
94.6\end{array}$ \\
\hline $\begin{array}{l}\text { Phosphorus } \\
\text { Potassium } \\
\text { Calcium } \\
\text { Magnesium } \\
\text { Sulfur } \\
\text { Sodium }\end{array}$ & $\begin{array}{r}2000 \\
7000 \\
2500 \\
1700 \\
950 \\
1000\end{array}$ & $\begin{array}{r}1700 \\
7000 \\
2200 \\
1600 \\
950 \\
700\end{array}$ & $\begin{array}{l}2000 \\
6000 \\
1400 \\
1400 \\
340 \\
700\end{array}$ & $\begin{array}{r}1100 \\
3000 \\
1600 \\
1400 \\
950 \\
300\end{array}$ & $\begin{array}{l}1200 \\
4000 \\
1900 \\
1400 \\
730 \\
300\end{array}$ & $\begin{array}{r}1100 \\
3000 \\
1900 \\
1300 \\
650 \\
300\end{array}$ & $\begin{array}{l}1100 \\
3000 \\
1800 \\
1400 \\
720 \\
400\end{array}$ & $\begin{array}{r}1200 \\
3000 \\
1900 \\
1400 \\
560 \\
400\end{array}$ & $\begin{array}{r}1300 \\
4000 \\
2000 \\
1600 \\
800 \\
400\end{array}$ & $\begin{array}{l}1800 \\
5000 \\
2900 \\
1500 \\
300 \\
500\end{array}$ & $\begin{array}{r}1700 \\
5000 \\
2200 \\
1300 \\
300 \\
600\end{array}$ \\
\hline $\begin{array}{l}\text { Fluorine } \\
\text { Zinc } \\
\text { Iron } \\
\text { Manganese } \\
\text { Copper } \\
\text { Boron } \\
\text { Arsenic } \\
\text { Selenium } \\
\text { Lead } \\
\text { Mercury }\end{array}$ & $\begin{array}{l}13 \\
13 \\
31 \\
50 \\
3 \\
4 \\
<.5 \\
-.0 \\
3.0 \\
0.14\end{array}$ & $\begin{array}{l}12 \\
13 \\
31 \\
65 \\
3 \\
3 \\
<.5 \\
-1 \\
3.1 \\
0.10\end{array}$ & $\begin{array}{l}14 \\
13 \\
27 \\
40 \\
4 \\
3 \\
<.5 \\
<.05 \\
4.0 \\
0.12\end{array}$ & $\begin{array}{l}7 \\
14 \\
32 \\
32 \\
2 \\
2 \\
<.5 \\
<.05 \\
3.5 \\
0.07\end{array}$ & $\begin{array}{l}19 \\
9 \\
64 \\
50 \\
3 \\
5 \\
<.5 \\
<.05 \\
3.0 \\
0.10\end{array}$ & $\begin{array}{l}13 \\
28 \\
44 \\
31 \\
4 \\
2 \\
<.5 \\
<.05 \\
4.0 \\
0.16\end{array}$ & $\begin{array}{l}12 \\
27 \\
44 \\
28 \\
3 \\
2 \\
<.5 \\
<.05 \\
3.0 \\
0.14\end{array}$ & $\begin{array}{l}8.4 \\
25 \\
42 \\
28 \\
4 \\
2 \\
<.5 \\
<.05 \\
3.0 \\
0.05\end{array}$ & $\begin{array}{c}0.2^{?} \\
26 \\
32 \\
25 \\
5 \\
2 \\
<.5 \\
<.05 \\
3.0 \\
0.01\end{array}$ & $\begin{array}{c}0.8 ? \\
22 \\
60 \\
28 \\
4 \\
5 \\
-- \\
-- \\
--\end{array}$ & $\begin{array}{c}0.7 ? \\
28 \\
70 \\
28 \\
3 \\
4 \\
- \\
- \\
- \\
-\end{array}$ \\
\hline
\end{tabular}

*All data in ppm unless otherwise indicated

$\star *$ Nitrogen Free Extract

***Total Digestible Nutrients

?Apparently analytical errors; these low fluoride concentrations are unlikely; results under evaluation. 
TABLE $X$

GRASS, ALFALFA, AND POTATO ANALYSES RESULTS*

(FROM AGRICULTURE TESTING AND CONSULTANTS, INC.)

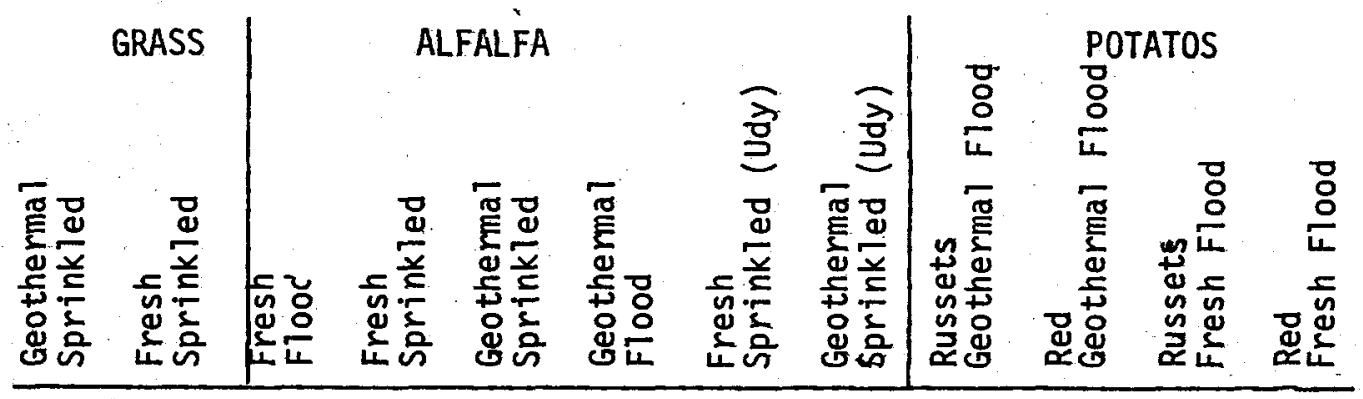

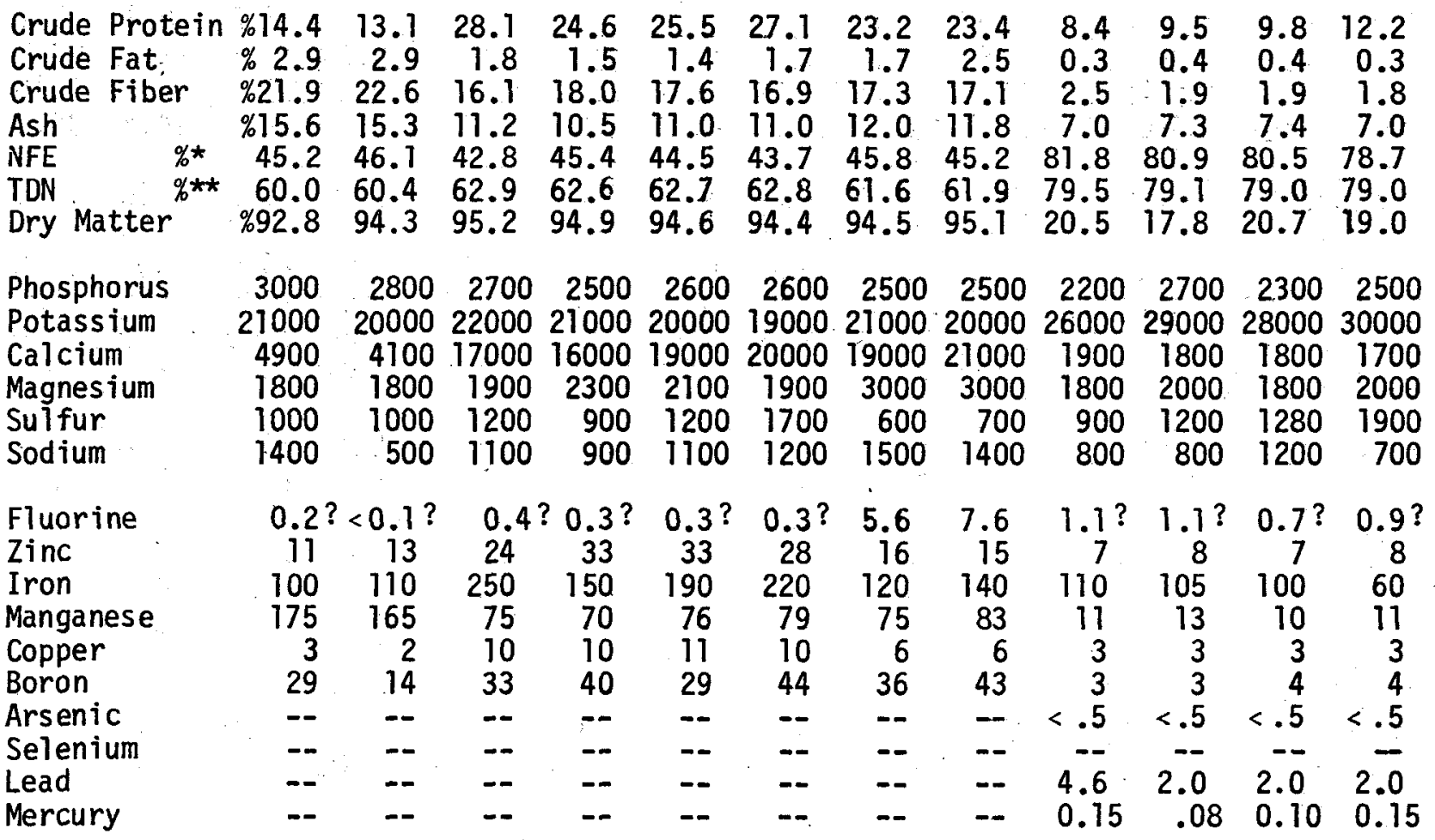

*All data in ppm unless otherwise indicated

$\star \star$ NFE Nitrogen Free Extract

***TDN Total Digestible Nutrients

? Results under evaluation, see footnote Table VII. 


\author{
TABLE XI \\ SURFACE FLUORIDE RESULTS FOR GRAINS \\ (MEASURED AT THE ANALYTICAL LAB OF IDAHO CHEMICAL \\ PROCESSING PLANT, ALLIEU CHEMICAL CO.)
}

\begin{tabular}{|c|c|c|c|}
\hline Grain Type & Irrigation Procedure & $\mathrm{gg} / \mathrm{gm}$ & \\
\hline Wheat & Fresh Water Sprinkled & 4.2 & \\
\hline Wheat & Geothermal Water Sprinkled & 35.4 & $26.7^{\star}$ \\
\hline Wheat & Geothermal Water Flooded & 4.4 & \\
\hline Oats & Fresh Water Sprinkled & 8.9 & \\
\hline Oats & Geothermal Water Sprinkled & 49.1 & $58.5^{*}$ \\
\hline Barley & Fresh Water Sprinkled & 0.71 & \\
\hline Barley & Geothermal Water Sprinkled & 8.7 & $8.4^{*}$ \\
\hline Barley & Geothermal Water Flooded & 0.7 & \\
\hline Barley & Fresh Water Flooded & 0.4 & . \\
\hline Potatos & Geothermal Water Flooded & 0.098 & \\
\hline Potatos & Fresh Water Flooded & 0.067 & \\
\hline
\end{tabular}

* Results for a second and different sample 
Another set of comparisons is found in Table XIII. In this case the comparişon results were taken from Composition of Cereal Grains and Forages ${ }^{3}$, a National Academy. of Sciences - National Research Council publication and is regionalized to be representative of Idaho. Also the analyses technique used reported data on a moisture-free bas is comparable to the crop data from the Raft River crops. The Raft River crops are observed to agree more favorably in this comparison, but additional investigation is needed to draw definite conclusions.

Preliminary fluoride results have been summarized in Table XIV The fluoride concentrations are observed to not exceed about $19 \mathrm{ppm}$ with most being considerably less. Results of fluoride toxicity studies have been printed such as in Reference 4 , and these concentrations do not represent a hazard when used as feedstuff for livestock. Reference 4, indicates that normal cattle feed stuffs can contain fluoride concentrations up to $15 \mathrm{ppm}$ and that from a chronic fluorosis standpoint, no adverse effects are noted for concentrations of $15-30 \mathrm{ppm}$. Borderline is $30-40 \mathrm{ppm}$, moderate at $40-60 \mathrm{ppm}$, severe $60-109 \mathrm{ppm}$ and acute fluorosis occurs at $250 \mathrm{ppm}$ and over. Also as observed in the comparison Tables XII and XIII, mineral concentrations and heavy metals in the geothermally watered crops have not emerged as a problem in the preliminary results.

Consequently the crop was considered safe, released for use and donated to the Idaho Youth Ranch.

Yield estimates indicate that there was essentially no difference between crops receiving Raft River water and those receiving geothermal water and that crops with yields comparable to those of the area could be produced. Figures 11 and 12 show wheat and barley near maturity and Figure 13 displays typical threshed grains. In the Darrington Experiment, typical alfalfa was raised and one additional (a fourth) alfalfa cutting was achieved compared to normal alfalfa experience in the valley. The Darrington fields were flood irrigated. No detrimental effects were observed. Fluoride results for the Darrington alfalfa are shown in Table XIV. 
TABLE XII

GRAIN DATA COMPARISON - RAFT RIVER

GEOTHERMAL VERSUS REFERENCE SOURCE 2

\begin{tabular}{|c|c|c|c|c|c|c|}
\hline & Wheat* $t$ & $\begin{array}{c}\text { Geo } \\
\text { Wheat** }\end{array}$ & 0ats* & $\begin{array}{c}\text { Geo } \\
\text { Oats** }\end{array}$ & Bärley* & $\begin{array}{c}\text { Geo } \\
\text { Barley** }\end{array}$ \\
\hline Protein & $\% 10.5-12.8$ & 9 & 10.3 & 11 & 10 & 9.9 \\
\hline Fat & 2.5 & 1.2 & 4.7 & 3.2 & 1.5 & 1.35 \\
\hline Carbohydrates & $\% 63-67$ & -- & 62.1 & $=-$ & 66.4 & - \\
\hline $\begin{array}{l}\text { Crude Fiber } \\
\text { Ash }\end{array}$ & $\begin{array}{ll}\% & 2.2 \\
\% & 1.5\end{array}$ & $\begin{array}{r}12.5 \\
5.8\end{array}$ & $\begin{array}{l}9.3 \\
2.6\end{array}$ & $\begin{array}{r}15.3 \\
6.8\end{array}$ & $\begin{array}{l}4.5 \\
2.6\end{array}$ & $\begin{array}{r}11.3 \\
6.8\end{array}$ \\
\hline $\begin{array}{l}\text { Potassium } \\
\text { Phosphorus }\end{array}$ & $\begin{array}{ll}\% & .45 \\
\% & .38\end{array}$ & $\begin{array}{l}.5 \\
.16\end{array}$ & $\begin{array}{l}.46 \\
.341\end{array}$ & .7 & .58 & .3 \\
\hline Sulfur. & .196 & .053 & .199 & .095 & .16 & .06 \\
\hline Magnesium & .157 & .14 & .143 & .17 & .18 & .135 \\
\hline Chlorine & .076 & -- & .10 & -- & .12 & -- \\
\hline Calcium & .05 & .16 & .095 & .25 & .05 & 19 \\
\hline Sodium & .024 & .05 & .087 & .1 & .077 & .035 \\
\hline Silicon & .012 & 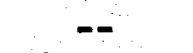 & & & & -- \\
\hline Iron & $\mathrm{ppm} 50^{\circ}$ & 45 & $70^{\circ}$ & 31 & $50^{\circ}$ & 43 \\
\hline Zinc & $\mathrm{ppm} 50$ & 11 & 27 & 13 & -- & 26 \\
\hline Manganese & $\mathrm{ppm} 40$ & 35 & 50 & 50 & 20 & 29 \\
\hline Copper & $\mathrm{ppm} 7$ & 4 & 4 & 3 & 5 & 4 \\
\hline Barium & ppm 8 & - & -- & -- & -- & -- \\
\hline Bromine & $\mathrm{ppm} \quad 6$ & -- & -- & -- & -- & $-\infty$ \\
\hline Boron & ppm 5 & 4 & 1.2 & 4 & -- & 2 \\
\hline Lithium & $\mathrm{ppm} 5$ & -- & -- & -- & -- & - \\
\hline Aluminum & $\mathrm{ppm} 3$ & -- & 5 & -- & -- & - \\
\hline Strontium & ppm & $\cdots$ & -. & - & -- & - \\
\hline Nickle & $\begin{array}{ll}\mathrm{ppm} & 1.4\end{array}$ & -- & 2 & - & .2 & -- \\
\hline Selenium & $\mathrm{ppm} \quad 1.1$ & $<0.05$ & - & -- & -- & $<0.05$ \\
\hline Titanium & $\mathrm{ppm} \quad .85$ & - & $8-$ & -- & -- & \\
\hline Fluorine & $\mathrm{ppm}$ & 16 & .4 & 13 & -- & 10.7 \\
\hline Lead & $\mathrm{ppm}$ & 3 & $\ldots$ & 3 & -- & 3.5 \\
\hline Molydbenum & $\mathrm{ppm}$ & -- & .4 & -- & .4 & -- \\
\hline Cobalt & $\mathrm{ppm}$ & - & .02 & -- & $<0.05$ & -- \\
\hline Iodine & $\mathrm{ppm}$ & -- & .011 & -- & .02 & -- \\
\hline Arsenic & $\mathrm{ppm}$ & $<0.5$ & .5 & $<0.5$ & $=$ & $<0.5$ \\
\hline
\end{tabular}

* From Reference 2, N. L. Kent, Technology of Cereals, Pergamon Press, 1966.

** Average of Geo Flood and Geo Sprinkle Sections from Raft River Crops

+ Yalues are for U.S. hard red spring wheat for protein, Manitoba for fat, crude fiber and ash, and mixed wheats from several sources for all other constituents. Values from Reference 2 are representative only in all cases including oats and barley. 
TABLE XIII

\section{GRAIN DATA COMPARISONS - RAFT RIVER}

Type of Grain

Barley

Oats

Wheat

\section{GEOTHERMAL VERSUS REFERENCE SOURCE $3 \dagger$ \\ Constituent}

(\%)

Comparison Source

\section{Crude Fiber \\ Ash \\ NFE}

Crude Protein

Calcium

Phosphorus

Copper (ppm)

Potassium

Magnesium

Iron

Manganese (ppm)

Sulfur

Sodium

Chlorine

Cobalt (ppm)

Zinc (ppm)

Crude Fiber

Ash

NFE

Crude Protein

Calcium

Phosphorus

Copper (ppm)

Potassium

Magnesium

Iron

Manganese (ppm)

Sulfur

Sodium

Chlorine

Cobalt (ppm)

Zinc (ppm)

\section{Crude Fiber \\ Ash}

NFE

Crude Protein

Calcium

Phosphorus

Copper (ppm)

Potassium

Magnesium

Iron

Manganese (ppm)

Sulfur

Sodium

Chiorine

Cobalt (ppm)

Zinc (ppm)
$4.8-1.0 .2$

$2.5-3.9$

$67.6-81.9$

$9.0-15.9$

$.05-0.13$

$0.33-0.51$

$1.3-20 *$

$0.5-0.68$

$0.01-0.17$

$0.004-0.01$ *

$2.4-30$ *

$0.01-0.06^{*}$

$0.09-0.17 *$

$0-0.32 *$

$11.9-21 *$

$12.4-15.9$

$3.6-5.5$

$62-69.4$

$9.2-14.0$

$0.04-0.48$ *

$0.05-1.02 *$

$2.4-25.8 *$

$0.22-0.89 *$

$0.03-0.29$ *

$0.002-.03 *$

$20-204^{*}$

$0.15-0.31$ *

$0.01-0.16$ *

$0.05-0.19 *$

$0-0.32 *$
Geothermal

Raft River Crop
$0.12-0.22^{*}$

11.3

71

9.5

.19

4

0.3

0.135

0.0043

29

0.06

0.035

0.19

26

15.3

6.8

63.7

11.

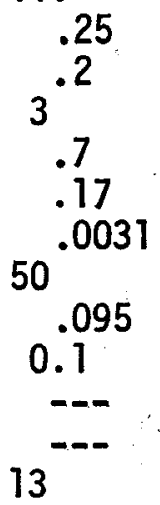

12.5

5.8

71.4

$9:$

0.16

0.16

4.

0.5

0.14

0.0045

35

$0-86^{*}$

$0.12-0.32 *$

$0-0.22 *$

$0.03-0.18^{*}$

$0.055-0.15 *$

$11.9-18.9$ *
.053

.05

11

(Table XIII continues on next page) 
Table XIII (Continued)

\begin{tabular}{|c|c|c|c|}
\hline Type of Grain & $\begin{array}{c}\text { Constituent } \\
(\%)\end{array}$ & Comparison Source & $\begin{array}{c}\text { Geothermal } \\
\text { Raft River Crop }\end{array}$ \\
\hline Alfalfa & $\begin{array}{l}\text { Crude Fiber } \\
\text { Ash } \\
\text { NFE } \\
\text { Crude Protein } \\
\text { Calcium } \\
\text { Phosphorus } \\
\text { Copper (pm) } \\
\text { Potassium } \\
\text { Magnesium } \\
\text { Iron } \\
\text { Manganese (ppm) } \\
\text { Sulfur } \\
\text { Sodium } \\
\text { Chlorine } \\
\text { Cobalt (ppm) } \\
\text { Zinc (ppm) } \\
\text { Iodine (ppm) }\end{array}$ & $\begin{array}{c}15.9-42.4 \\
6.7-15.3 \\
36.7-49.1 \\
9.3-24.7 \\
0.76-2.98 \\
0.16-0.43 \\
4.4-37.9^{\star} \\
0.43-2.74 \\
0.03-0.84^{\star} \\
0.004-0.164^{\star} \\
7.9-100^{\star} \\
0.2-0.73^{\star} \\
0.01-0.33^{\star} \\
0.06-0.54^{\star} \\
.02-0.31^{\star} \\
9.9-29.1^{\star} \\
59-293^{\star}\end{array}$ & $\begin{array}{c}17.3 \\
11.0 \\
44.1 \\
26.3 \\
1.95 \\
0.26 \\
10.5 \\
1.95 \\
0.2 \\
.019 \\
76 \\
0.12 \\
0.11 \\
--- \\
30 \\
-.--\end{array}$ \\
\hline
\end{tabular}

*Range for all samples in source document (not regionalized)

+Reference Source 3 - Composition of Cereals, Grains and Forages, Publication 585, National Academy of Science, National Research Council, 1958. 
TABLE XIV

FLUORIDE IN CROP SAMPLES FROM EXPERIMENTAL PLOTS

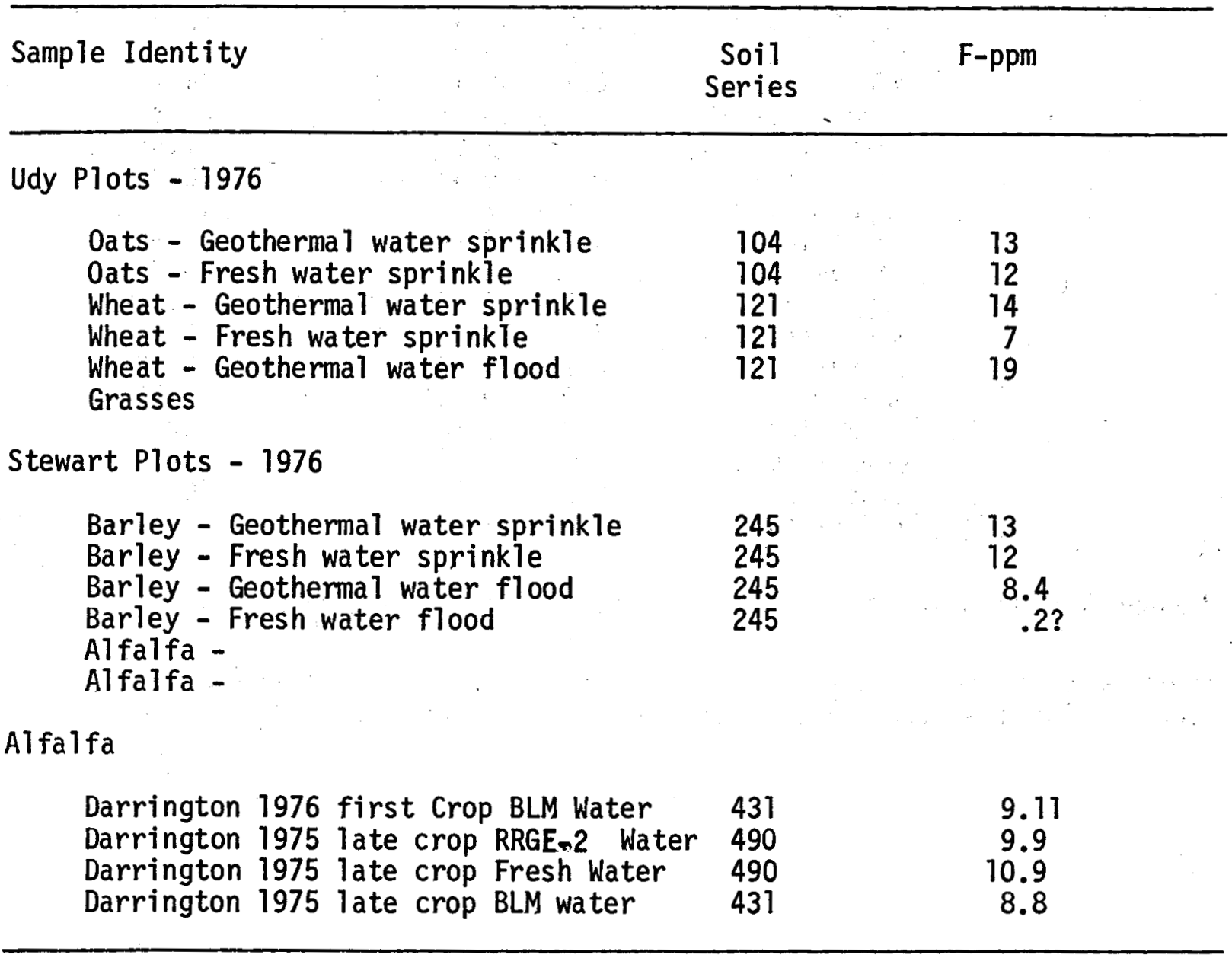

?This apparently was an analytical error. It is unlikely that barley would contain such a small amount of fluoride. 


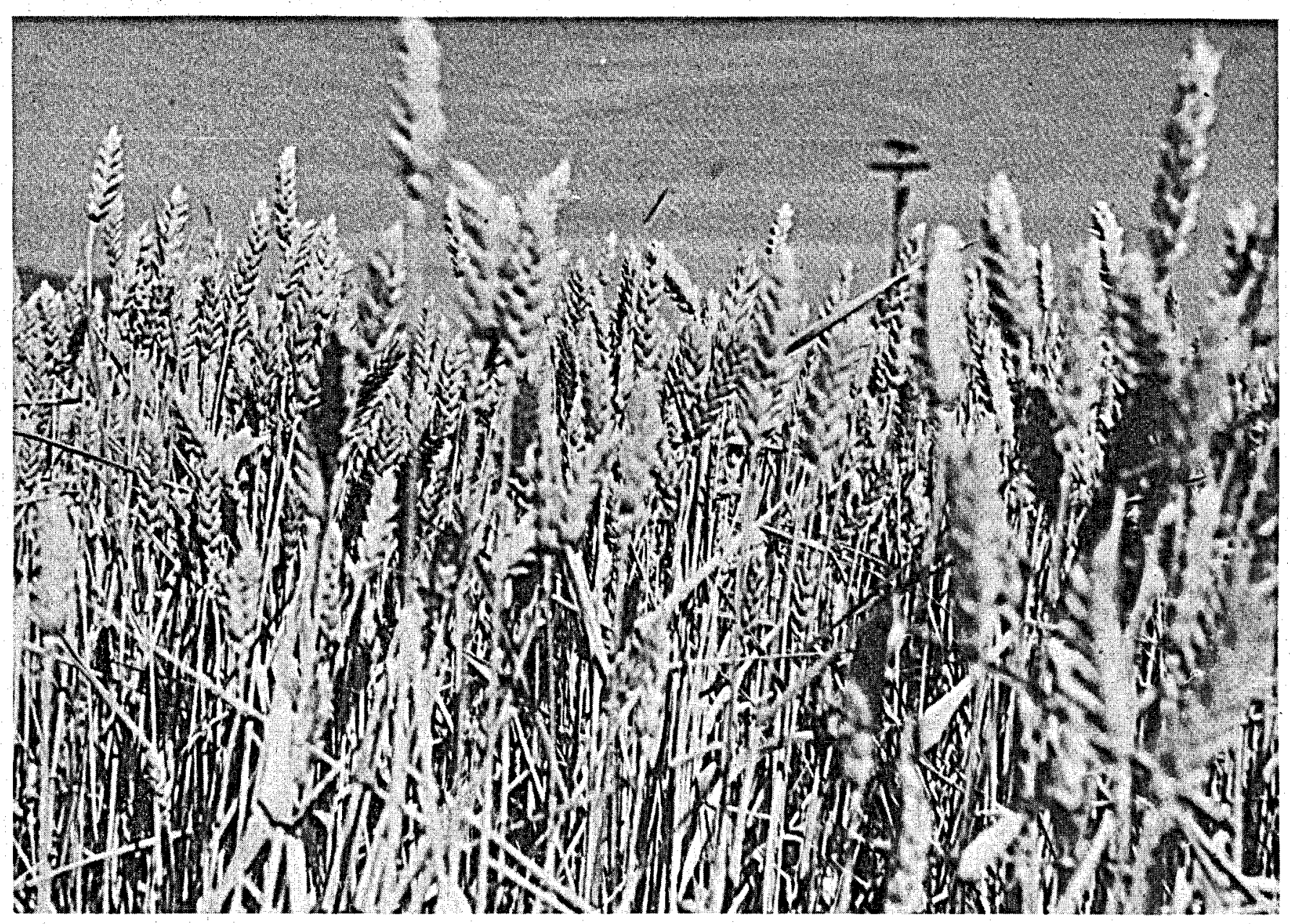

Fig. 11 Mature wheat on Udy plot 


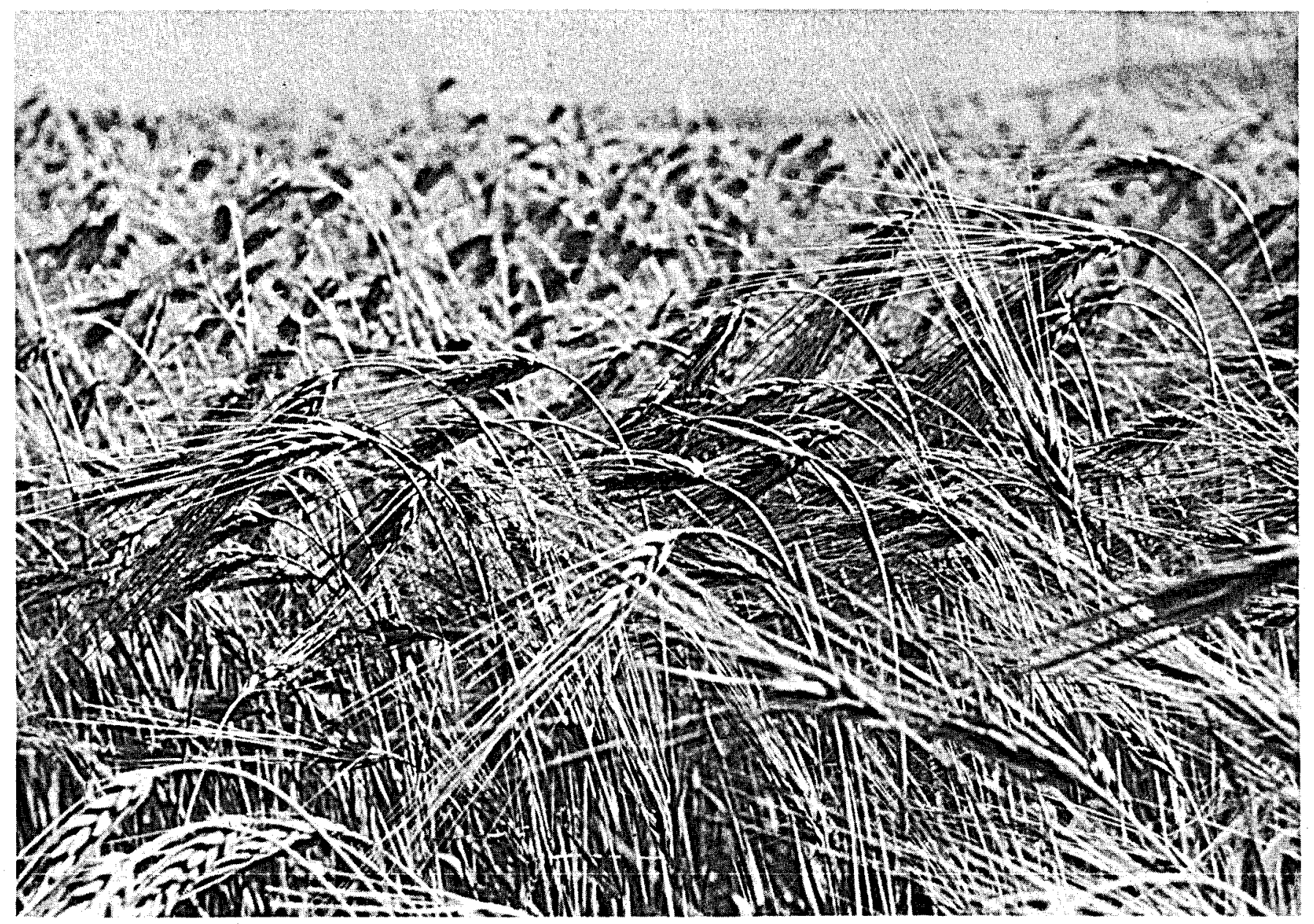

Fig. 12 Mature barley on Stewart plot 


\section{RAFT RIVER IRRIGATION EXPERIMENT Typical Grains}
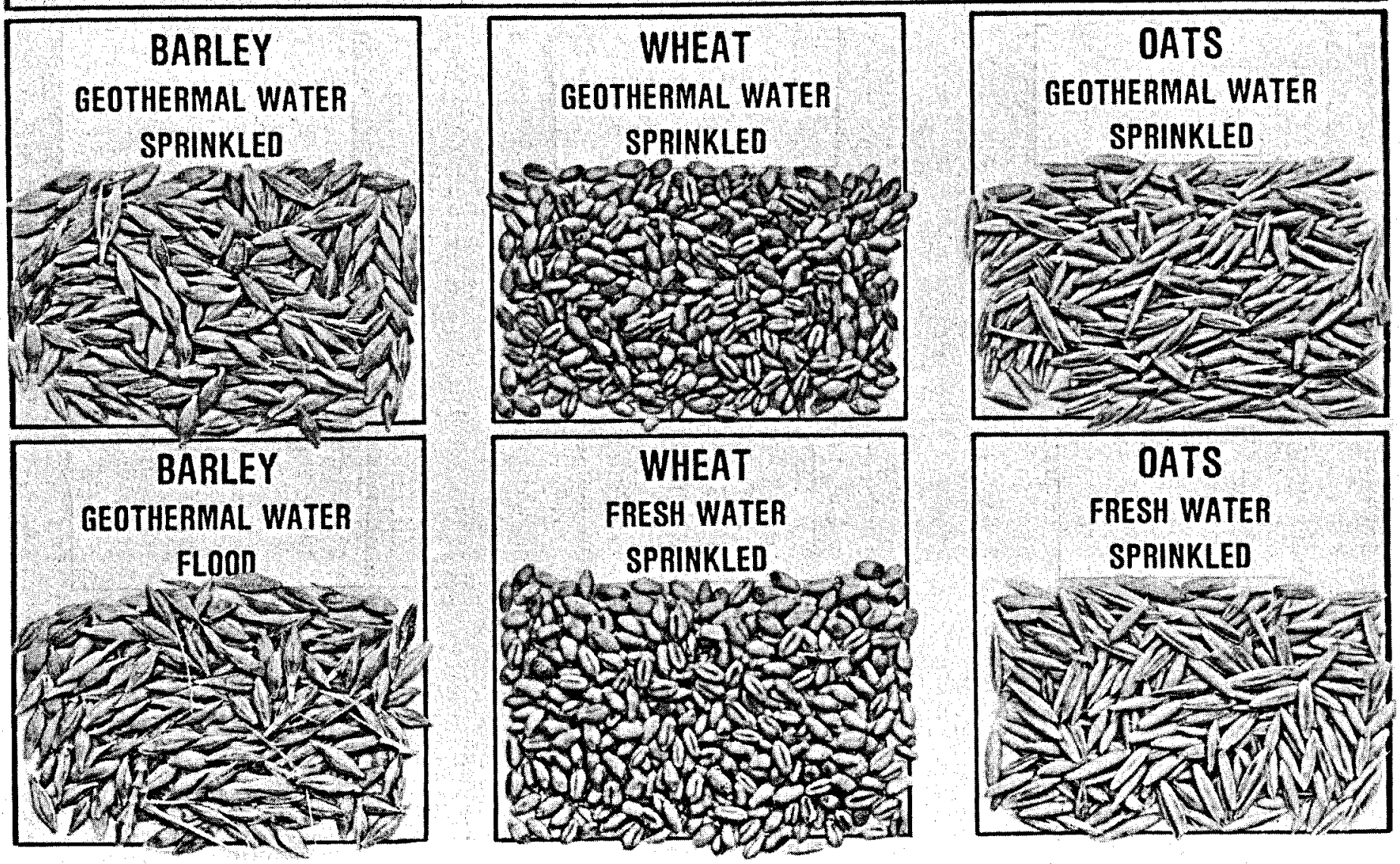

Fig. 13 Typical threshed grains from experiment 


\section{v. CONCLUSIONS AND FOLLOW-ON}

The setting up of the experiment, assembling of the necessary hardware, and haryesting of a crop after a late spring start was a major accomplishment. Many difficulties were encountered as is always the case when 1 and is irrigated and put into production for the first time such as the Udy plot. Soil erosion caused by surface irrigation on this plot made it necessary to do some land leveling and reseeding. The crops that were produced on this land were quite successful considering the land had not previously been leached, cultivated or fertilized. There were some problems encountered in assembling the necessary equipment and supplying the required water as soon as needed by the crops and again about midway through the growing season on some fresh water sections because of water exchange policies (Raft River) that required resolution. These difficulties undoubtedly had a detrimental effect on overall crop quality. Also, as with any newly assembled system, many equipment component difficulties had to be overcome.

But a successful crop was produced. Yield estimates indicate that there was essentially no difference between the crops receiving geothermal waters and those receiving the fresh Raft River source. The results also were indicative that crops with geothermal water would produce yields typical of those of the area. An extensive sampling activity for crop, soil, water and weather data for analyses was formulated and implemented. The results of the various analyses are not totally complete but preliminary results indicate that crop constituents such as fluoride and mineral concentrations are virtually the same between the geothermally watered and fresh watered crops. The analyses are due to continue and the results examined in more detail for subsequent reporting. Of particular interest will be the effect of year after year accumulation of minerals in the soil, and the effect of the winter-spring leaching of the soil.

Follow-on phases for this experiment will see refinement in practices and analyses. An earlier spring start will be implemented for Phase 2 along with improvement in the water delivery scheduling. Equipment will be provided to accurately measure the amount of water being applied to field crops and water lost in runoff will be avoided. A "growing degree day" system will be implemented along with soil water content instrumentation to more accurately provide the required amount of water. Soil and water temperatures will be more precisely monitored. The sampling and analyses will be assigned to one supervising body for direction. Some changes in crop plan will also be implemented. The Udy plot will be deyoted to forage crops with the Stewart plot devoted in part to potatos and sugar beets on a significant scale. Samples of typical grains, potatos and sugar beets from other regions of the state will be included in the sample analysis to obtain an accurate control comparison. Fluoride, heavy metals behavior, soil alterations, etc. will continue to receive emphasis. Additional investigation will be directed to establishing the differences in plant response with sprinkled geothermal water versus flood irrigation. Water criteria today are based on surface applications not sprinkler but many crops may be less tolerant to salts and geothermal waters during sprinkler applications. The groundwork and data bases for investigating 
these problems were successfully accumulated in this first phase of the experiment, and the follow-on phases should contribute significantly to understanding the use of geothermal waters in irrigation practices and environmental impact. 


\section{yI. REFERENCES}

1. Growing Degree Day Systems For Idaho, Bul letin No. 551, Idaho Agriculture Experiment Station, A Uniyersity of Idaho College of Agriculture Publication, January 1976.

2. N. L. Kent, Technology of Cereals, Pergamon Press, 1966.

3. Composition of Cereals, Grains and Forages, Publication 585. National Academy of Sciences - National Research Council, 1958.

4. James L. Shupe, DVM., Fluorine Toxicosis and Industry, American Industrial Hygiene Association Journal, Volume 31, March-Apri1, 1970. 

APPENDIX A SOIL DESCRIPTION *

SOILS

The soils in the area are mostly young alluvial soils and are highly variable. A map. Figure 1, shows the soil series in the area of development wells. As noted in the descriptions, several soils are not suitable for irrigation.

\section{General Soil Descriptions}

The descriptions of the soil series and site conditions were modified from a draft prepared by the Soil Conservation Service. The soil series names should be considered as tentative.

\section{Aysees-Hiko Peak Complex}

These are a mixture of soils formed in alluyium from mixed sources with influence from volcanic tuff. They are located on dissected piedmont plains at elevations of 4,600 to 5,600 feet.

Aysees Loam, 4 to 12 percent slope, is 50 percent of the area. Hiko Peak loam, 4 to 12 percent, is 45 percent of this unit. The occurrence of each depends on the mixing of the underlying gravel with the overlying mantle of finer soil and the thickness of the overlying mantle. It is difficult to discern the occurrence of one soil or the other without extensive excavation. The Aysees loam consists of deep, somewhat excessively drained soil. In a typical profile, the surface layer is a pale brown and light brownish-gray loam and silt loam 6-inches thick. The substratum is a very pale brown and light gray, very gravelly sandy loam and sand. This is underlain by interstratified layers of yery pale brown and light brownish-gray, very gravelly loam, very gravelly sandy loam, sand and gravelly sand 56 inches thick. The soil is calcareous with a zone on lime accumulation at a depth of 6 to 25 inches. It is moderately and strongly alkaline and strongly saline. Permeability is moderately rapid. Effective rooting depth is 60 inches or more. Available water capacity is 2.4 to 3.6 inches. Surface runoff is medium and erosion hazard is moderate. Soil blowing hazard is slight.

The Hiko Peak soil consists of deep, well drained soil. In a typical profile the surface layer is a pale brown loam 4 inches thick. The substratum is a stratified pale brown, light gray and very pale brown, very gravelly loam and very graveliy sandy loam 43 inches thick. The next underlying layer is a pale brown sandy loam to a depth of 65 inches. The soil is calcareous with a zone strong lime accumulation at a depth of 4 to 28 inches. This soil is moderately to strongly alkaline and strongly saline below a depth of 14 inches. Permeability is moderately rapid. Effective rooting depth is 60 inches or more. Available water capacity is 4.2 to 5.4 inches. Surface runoff is medium and erosion hazard is moderate. Soil blowing hazard is slight.

*Excerpts from data prepared by Utah State University Consul tants. A-1 


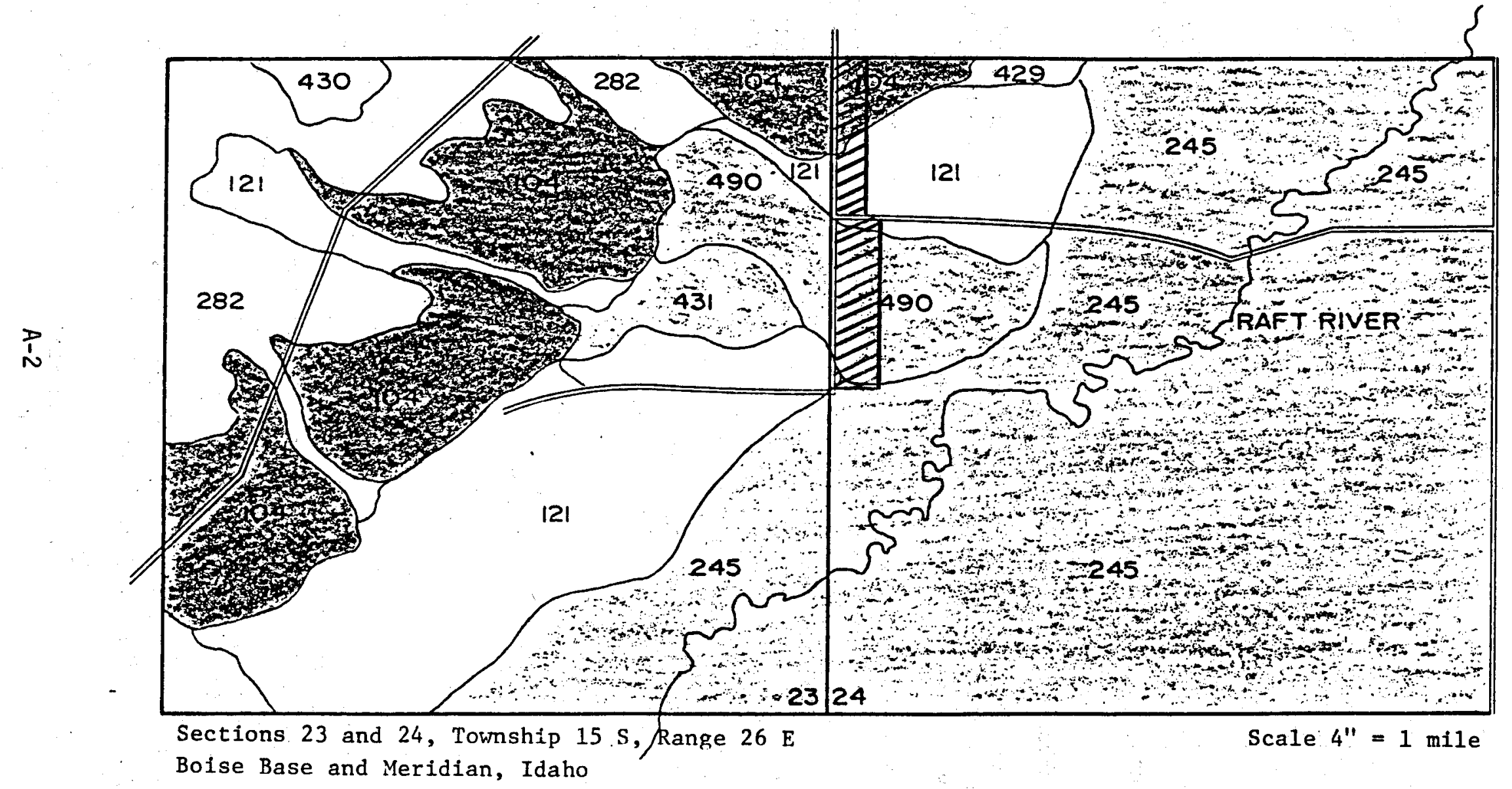

Figure 1. Soil Series Map 
These soils are used mostly for grazing. Other uses are wild ife habitat, construction, and sources of gravel and fill material. These soils are not suitable for irrigated farmland and if irrigated, a sprinkler system should be provided.

This soil supports small populations of jackrabbits, cottontails,. coyotes, badgers, sma 11 rodents, sage grouse, mourning doves, and nongame birds. Increasing grass and forb portion of the flora and a reduction of brush by good grazing practices will benefit wildlife populations. Smal1 scattered areas of brush control and reseeding to wheat grasses will also benefit wildife populations.

Natural vegetation consists of big sage, greasewood, shadscale, squirreltail and Idaho fescue. Severe overgrazing by domestic 1 ivestock in the past has reduced the grass and allowed the increase of unpalatable brush species and the poisonous weed halogeton. A rest rotation system of grazing involving the judicious placement of salt stations and watering facilities does much to rehabilitate depleted range. Brush control and reseeding to crested wheatgrass has been successful in some areas.

\section{Bram Silt Loam, 0 to 2 Percent Slopes}

This soil consists of deep moderately well drained soil on low terraces and alluvial fans. Elevation is 4,300 to 4,900 feet. It is formed in alluvium from mixed sources.

Included in mapping is about 10 percent of a soil similar to Bram except it is strongly saline alkali affected and has a clay or clay loam texture. This is in old channel oxbows or depressions.

In a typical profile the surface layer is a light brownish-gray silt loam to a depth of 4 inches. This is underlain by 1 ight brownishgray or pale brown silt loam or silty clay loam to a depth of 60 inches. The soil is strongly to very strongly alkaline and calcareous with a concentration of lime between 4 and 30 inches. The soil is strongly affected by salinity. A careful check of these soils will probabiy reveal that they are fine silty.

Permeability is moderately slow. Effective rooting depth is 40 to 60 inches. Available water capacity is 2.5 to 4.0 inches. Surface runoff is slow and erosion hazard is slight. Soil blowing hazard is moderate.

This soil is used for wild ife habitat, rangeland, and 1 imited irrigated cropland. Attempts to improve this soil and deyelop it for more intensive uses have shown it is not usually economical.

Irrigated farmland is usually cropped to sugar beets, alfalfa hay or barley. Addition of sulfur to lower the pH of the soil have shown some short term benefits to increased cropping but the drainage that is needed to properly leach this soil is hampered because no outlets are available. The best irrigated crop for this soil is salt intolerant irrigated pasture. 
Irrigation methods suited to this soil are border, furrow, corrugation, and sprinklers. Leaching irrigations are needed to move the salt from the soil, howeyer, these tend to aggravate the soil water table.

This soil in native condition furnishes a source of cover and nesting for upland game bird wildlife. When cultivated, it is a good source if crops are left unharvested. Because of severe soil salinity and alkali problems, it is difficult to manage for vegetation other than salt tolerant species. Openland wildlife is the best suited wildlife use of this area.

The potential native vegetation on this soil is alkali sacaton, basin wild rye, inland saltgrass, alkali bluegrass and greasewood. When the range is overused by 1 ivestock, the grasses decrease the the greasewood increases. When the site is dominated by greasewood, it is advisable to kill the brush species and allow the grass to fill in.

\section{Sweetzer Silt Loam, 0 to 2 Percent Slopes}

This Sweetzer soil consists of deep, well drained soil on floodplains and low terraces of valley bottoms at elevations of 4,700 to 5,200 feet. Included in mapping is about 5 percent of a dark grayish brown silt loam soil that is very gravelly loam at a depth of 20 to 40 inches. It has a zone of lime accumulation below 20 inches. The unit has many small areas with a silty clay loam surface texture.

In a typical profile, the surface layer is dark grayish-brown and grayish-brown silt loam 13 inches thick. The substratum is light brownish-gray stratified silt loam, silty clay loam, and loam over very gravelly loamy sand at a depth of 54 inches. Permeability is moderately slow. Effective rooting depth is 40 to 60 inches. Available water capacity is 8.5 to 12 inches. Surface runoff is slow or yery slow and erosion hazard is slight. Soil blowing hazard is slight.

These soils are used mostly for irrigated cropland for such crops as alfalfa hay', barley, and wheat.

Irrigation methods suited to this soil are border, furrow, corrugation and sprinklers. The system used should be designed to replenish the moisture in the plant root zone without excessive surface runoff or deep percolation. Excessive deep percolation will cause the water table to rise.

This Sweetzer soil can support large populations of cottontail rabbits, upland game birds such as ring-necked pheasants, mourning doves, and Hungarian partridge and songbirds. These animals obtain their food and shelter primarily from cropland. Additional vegetation such as Russian olive, multiflora rose, and tall wheatgrass can be planted along fence rows, ditchbanks and in odd corners to provide shelter and nesting areas. 
Soils of the area haye been sampled and analyzed. Some of the soils had been previously irrigated with geothermal waters while others had "regular water" of unknown composition. The data in Table 1 gives a characterization of these soils and indicates the salinities are low. The sodium hazards margin are given in Table 2.

Water from we11 RRGE-2 was discharged on some uncultivated brush land in the area. Samples of soil were taken from an area receiving the water as well as from unwatered soil. The results are given in Table 3.

Prior to irrigating the Udy and Stewart test areas, bulk samples were taken from each field and a chemical characterization was made. The results are given in Table 4 . 
SOIL ANALYSIS ON SAMPLES TAKEN AT RAFT RIVER NEAR RRGE-2

\begin{tabular}{|c|c|c|c|c|c|c|c|c|c|}
\hline Soil & $\begin{array}{l}\text { Sample } \\
\text { Number }\end{array}$ & $\begin{array}{l}\text { Depth of } \\
\text { Sample, In. }\end{array}$ & $\mathrm{pH}$ & $\begin{array}{c}\mathrm{mmhos}_{\mathrm{EC}} / \mathrm{cm} \\
\mathrm{e}\end{array}$ & SEC & $\begin{array}{l}\mathrm{me} / 100 \mathrm{~g} \\
\mathrm{H}_{2} \mathrm{O} \mathrm{Na}\end{array}$ & Sat.\% & $\begin{array}{r}\mathrm{me} / 100 \mathrm{~g} \\
\text { Ext.Na }\end{array}$ & $\begin{array}{l}\text { Exchangeable } \\
\text { Sodium } \%\end{array}$ \\
\hline 490 & $\begin{array}{c}1 \\
\text { Regular } \\
\text { Water }\end{array}$ & $\begin{array}{l}0-5 \\
5-10\end{array}$ & $\begin{array}{l}8.0 \\
7.9\end{array}$ & $\begin{array}{l}2.0 \\
3.6\end{array}$ & $\begin{array}{l}21.8 \\
21.5\end{array}$ & $\begin{array}{l}.4 \\
.8\end{array}$ & $\begin{array}{l}38 \\
43\end{array}$ & $\begin{array}{l}2.4 \\
2.4\end{array}$ & $\begin{array}{l}9.0 \\
7.5\end{array}$ \\
\hline 490 & $\begin{array}{c}2 \\
\text { Regular } \\
\text { Water }\end{array}$ & $\begin{array}{l}0-5 \\
5-10\end{array}$ & $\begin{array}{l}8.3 \\
8.5\end{array}$ & $\begin{array}{l}2.4 \\
3.1\end{array}$ & $\begin{array}{l}20.5 \\
20.2\end{array}$ & $\begin{array}{l}.6 \\
.9\end{array}$ & $\begin{array}{l}37 \\
45\end{array}$ & $\begin{array}{l}3.0 \\
2.9\end{array}$ & $\begin{array}{r}11.7 \\
9.7\end{array}$ \\
\hline 490 & $\begin{array}{l}3 \\
\text { We11 \#2 } \\
\text { Water }\end{array}$ & $\begin{array}{l}0-5 \\
5-10\end{array}$ & $\begin{array}{l}8.1 \\
8.1\end{array}$ & $\begin{array}{l}1.6 \\
1.7\end{array}$ & $\begin{array}{l}21.0 \\
21.5\end{array}$ & $\begin{array}{l}.6 \\
.6\end{array}$ & $\begin{array}{l}41 \\
46\end{array}$ & $\begin{array}{l}3.0 \\
3.5\end{array}$ & $\begin{array}{l}11.5 \\
13.3\end{array}$ \\
\hline
\end{tabular}

On November 6, 1975, soil samples were taken from alfalfa fields south west of well \#2. Fields represented by samples 1 and 2 had received "regular water". There is no record of the composition of the regular water. Fields represented by sample 3 received some water from we11 \#2 during the period September - October, 1975. From the data it is not possible to measure an effect of the water from wel1 \#2 on the soil. These data may serve as references for future treatments.

$E C_{e}$ - Specific Electrical Conductance

CEC - Cation Exchange Capacity (a measure of the qulaity of the soil; CEC = me/100 gms of sample)

me - mili equivalents (ml x Normality - me; $\mathrm{ppm}$ *mg/1) $\div$ Form $W t$. $=\mathrm{me} / 1$ )

H2O Na - Water Soluble Sodium

Sat. \% - Saturation Percentage

Ext. Na - Extractable Sodium 
TABLE II

SOIL ANALYSIS FOR AGRICULTURAL SUITABILITY, INTERPRETATION KEY

\begin{tabular}{|c|c|c|c|}
\hline $\begin{array}{l}\text { Degree of Hazard } \\
\text { to Soil Structure }\end{array}$ & $\begin{array}{l}\text { Sodjum Status } \\
(\mathrm{ESP})^{1}\end{array}$ & $\begin{array}{l}\text { Effect } \\
\text { on Plant Growth }\end{array}$ & $\begin{array}{r}\text { Salinity } \\
\left(\mathrm{EC} \times 10^{3}\right) \\
\mathrm{m} \text { mhos } / \mathrm{cm} \\
\end{array}$ \\
\hline Low to slight & $0-10$ & $\begin{array}{l}\text { Negligible on } \\
\text { any crop }\end{array}$ & $0-2$ \\
\hline Marginal & $10-20$ & $\begin{array}{l}\text { Sensitive Crops } \\
\text { restricted }\end{array}$ & $2-4$ \\
\hline High & $20-40$ & $\begin{array}{l}\text { Many crops } \\
\text { restricted }\end{array}$ & $4-8$ \\
\hline Very High & 40 & $\begin{array}{l}\text { Only tolerant crops } \\
\text { satisfactory }\end{array}$ & $8-16$ \\
\hline \multicolumn{2}{|c|}{$\begin{array}{l}\text { 1. ESP: Exchangeable sodium percent } \\
\text { 2. SAR: Sodium adsorption ratio of } \\
\text { saturation extract }\end{array}$} & $\begin{array}{l}\text { Few tolerant crops } \\
\text { satisfactory }\end{array}$ & $16-$ \\
\hline
\end{tabular}


SALT EXCHANGE CAPACITY AND EXCHANGEABLE SODIUM CONTENT OF -BRUSH SOIL WITH AND WITHOUT GEOTHERMAL WATER* FROM RRGE-2

\begin{tabular}{|c|c|c|c|c|c|c|c|c|c|}
\hline Soil & $\begin{array}{l}\text { Sample } \\
\text { Number }\end{array}$ & $\begin{array}{l}\text { Depth and } \\
\text { Treatment }\end{array}$ & $\mathrm{pH}$ & $\begin{array}{c}\text { mmhos/cm } \\
E C_{e}\end{array}$ & CEC & $\begin{array}{l}\mathrm{me} / 100 \mathrm{~g} \\
\mathrm{H}_{2} \mathrm{O} \mathrm{Na}\end{array}$ & Sat \% & $\begin{array}{c}\mathrm{me} / 100 \mathrm{~g} \\
\text { Ext. } \mathrm{Na}\end{array}$ & $\begin{array}{l}\text { Exchangeable } \\
\text { Sodium } \%\end{array}$ \\
\hline 104 & 1 & $\begin{array}{l}0-10 \text { in } \\
\text { no water }\end{array}$ & 8.3 & 1.9 & 20.5 & .5 & 36 & 3.9 & 16.4 \\
\hline 104 & 2 & $\begin{array}{l}0-10 \text { in } \\
\text { water from } \\
\text { well }\end{array}$ & 8.2 & 5.8 & 16.8 & 1.3 & 37 & 5.5 & 24.8 \\
\hline
\end{tabular}

*On November 6, 1975, two soil samples were taken from an uncultivated brush area northeast of well \#2. Sample 1 area had received no applied water. Sample 2 area received water through a sprinkler system from well \#2. Water was not applied equally over the entire treated area. Most of the sample 2 area received water for a period of 24 hours. No records were available on the amount of water applied.

The results are not conclusive but suggest that as a result of the applied water, the salinity and exchangeable sodium of the soil were increased as a result of the water disposal.

$E C_{e}$ - Specific Electrical Conductance

CEC - Cation Exchange Capacity (a measure of the quality of the soil; CEC = me/100 gms of sample)

me - mili equivalents $(\mathrm{ml} \times$ Normality $=\mathrm{me} ; \mathrm{ppm}(\mathrm{mg} / 1) \div$ Form. $W \mathrm{t} .=\mathrm{me} / 1)$

H2O Na - Water Soluble Sodium

Sat \% - Saturation Percentage

Ext. Na - Extractable Sodium 
TABLE IV

ANALYTICAL DATA ON SOIL FROM THE UDY AND STEWART TRIAL AREAS*

\begin{tabular}{|c|c|c|c|c|c|c|c|c|}
\hline Sample & $\begin{array}{l}\text { Depth of } \\
\text { Sample, in. }\end{array}$ & $\mathrm{pH}$ & $\begin{array}{c}\text { mmhos } / \mathrm{cm} \\
E C_{e}\end{array}$ & CEC & $\begin{array}{l}\mathrm{me} / 100 \mathrm{~g} \\
\mathrm{H}_{2} \mathrm{O} \mathrm{Na}\end{array}$ & Sat. \% & $\begin{array}{l}\mathrm{me} / 100 \mathrm{~g} \\
\text { Ext. Na. }\end{array}$ & $\begin{array}{l}\text { Exchangeable } \\
\text { Sodium } \%\end{array}$ \\
\hline Udy & $0-6$ & 8.2 & 1.5 & 18.9 & .4 & 39.7 & 2.2 & 9.5 \\
\hline Stewart & $0-6$ & 8.0 & 2.9 & 25.0 & 1.2 & 57.8 & 5.4 & 16.9 \\
\hline
\end{tabular}

*Bulk soil samples were taken May 17, 1976, from throughout each of the areas. Subsamples were then taken of each for analysis. These data should serve as reference information obtained prior to any treatments.

$E C_{e}$ - Specific Electrical Conductance

CEC - Cation Exchange Capacity (a measure of the quality of the soil; CEC = me/100 gms of sample)

me - mili equivalents (ml x Normality - me; ppm $(\mathrm{mg} / 1) \div$ Form. Wt. $=\mathrm{me} / 1$ )

H2O Na - Water Soluble Sodium

Sat \% - Saturation Percentage

Ext. Na - Extractable Sodium 
APPENDIX B

WATER QUALITY 


\section{APPENDIX B}

\section{WATER QUALITY}

Numerous analytical determinations have been made to determine the composition of the dissolved substances in the geothermal waters from the wells in the area. Table 1 contains typical data from these determinations. For irrigation, the trace element compositions are satisfactory as indicated by the trace element standards given in Table 2.

The total soluble salts, the amount and proportion of sodium (sodium adsorption ratio, SAR) and the fluorides are the potentially troublesome constituents in the effluent waters, Table 3.

The quality ratings indicate that in general, the quality of the waters are poor. This is further evidenced from the interpretations shown in Figure 3 and the comments about water quality classes taken from the 2nd Edition of Irrigated Soils by Thorne and Peterson.

\section{Water Quality Classes}

\section{Conductivity Classes}

C-1 (0 to 250 micromhos): Low sálinity water can be used for irrigation with most crops on most soils with little likel ihood that soil salinity will develop. Some leaching is required, but this will occur under normal irrigation practices except in cases where the soil has extremely low permeability.

C-2 (250 to 750 micromhos): Moderate sal inity water can be used for irrigation with all but extremely salt-sensitive plants when grown on soils of high to medium permeability. With soils of low permeability, some leaching precautions, and at times, the selection of plants of moderate salt tolerance, may be necessary. Usually ordinary irrigation practices will provide ample leaching.

C-3 (750 to 2,50 micromhos): Medium to high salinity water should be used only on soils of moderate to good permeability. Regular leaching is often needed to prevent serious salinity. Special management for salinity control will of ten be needed, and plants with moderate to good salt tolerance should be selected.

C-4 (2,250 to 4,000 micromhos): High salinity water can be used for irrigation only on soils of good permeability and where special leaching is provided to remove excess salt. Only salt-tolerant crops should be grown. 


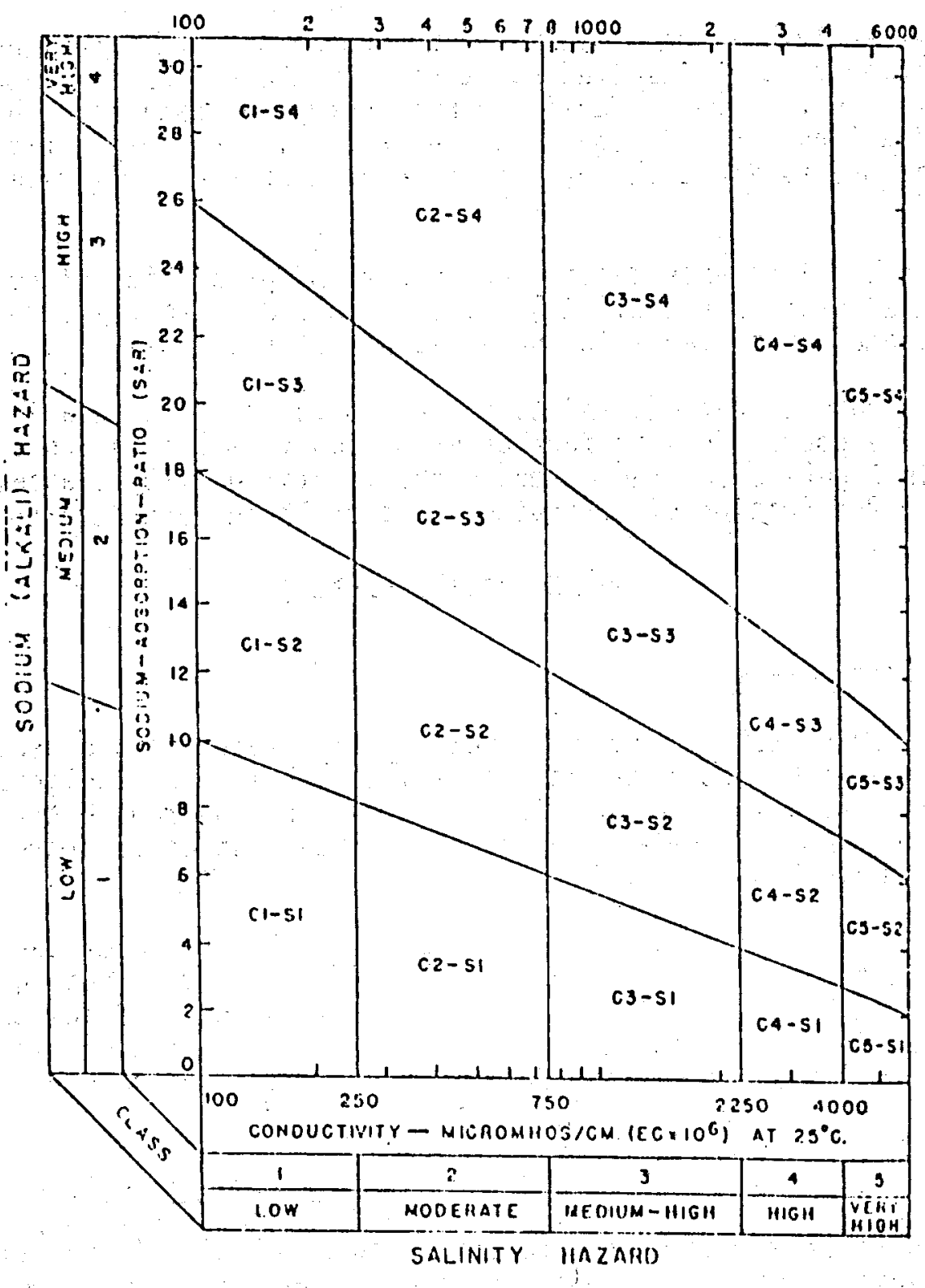

Figure 3.

Diagram for determining the quality rating of an irrigation water from its sodium adsorption ratio and electrical conductivity from Thorne and-Peterson, Irrigated Solls, 2nd Ed., Blakiston Co. Publishers. 
TABLE I

TRACE ELEMENT TOLERANCES FOR IRRIGATION WATERS

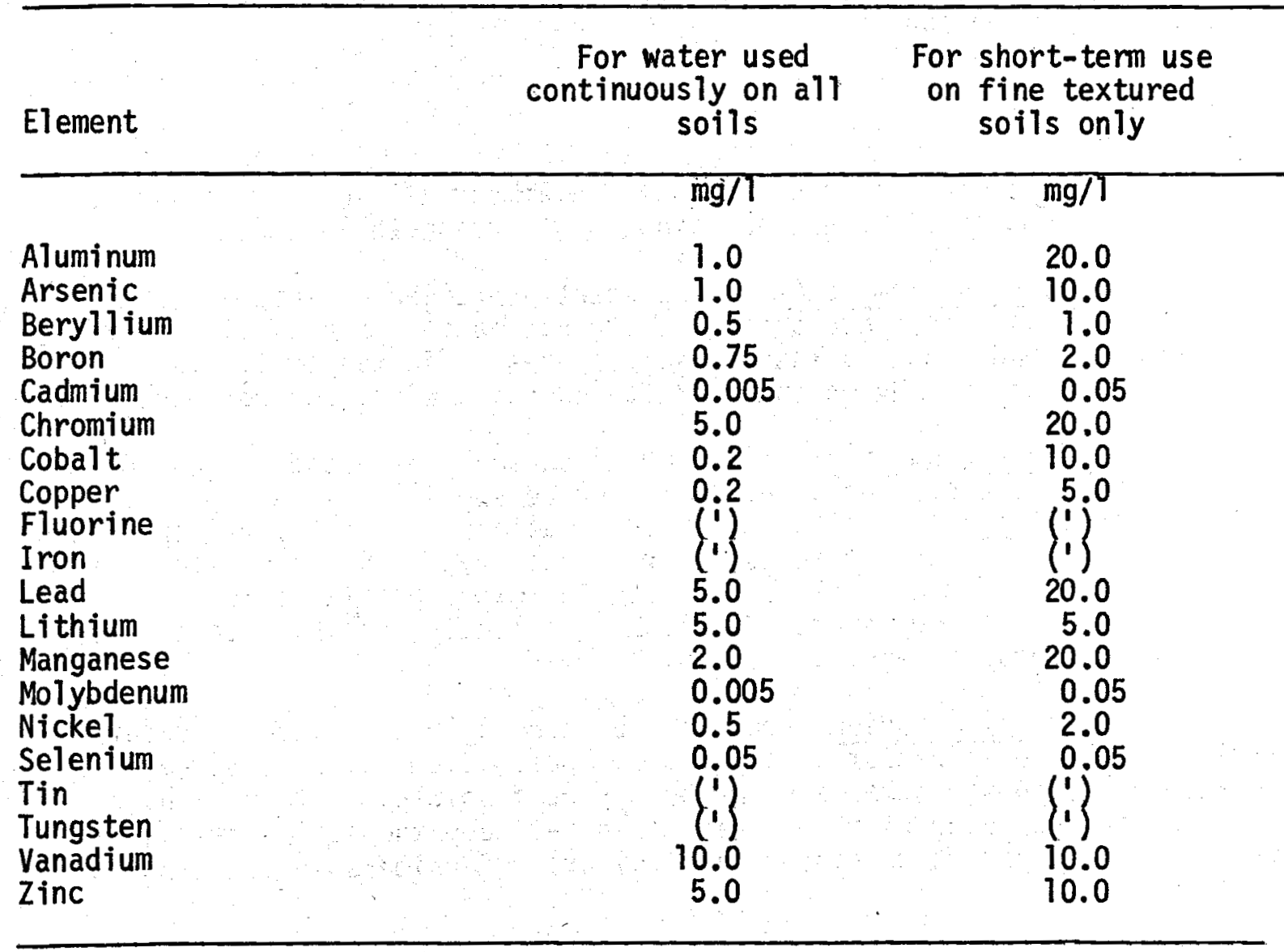

(1)

Fluoride: The most serious effect of fluoride is not its effect on plant growth, but the ultimate effect on the consuming animal including man. The uptake of fluoride by plants is restricted both by a combination of the element with soils, and a discrimination against fluoride by plant roots. Some plant species do accumulate large amounts of fluoride, but for the most part they are not consumed by man or livestock. The prinicpal pathway for fluoride poisoning then is through direct imbibition of toxic waters or plant accumulation of fluoride from the air. Unknown is the amount of fluoride adsorbed by the foilage when sprinkle irrigation is used with water contáining high levels of fluoride.

Iron: Iron is not likely to be a problem with irrigation waters. In those instances where imbalances due to excess iron develop, they can be controlled with management practices. 
C-5 (4,000 to 6,000 micromhos): Yery high salinity water is generally undesirable for irrigation and should be used only on highly permeable soils, with frequent leaching and with plants of high salt tolerance.

C-6 (above 6,000 micromhos): Excessive salinity water should not be used for irrigation.

\section{Sodium Classes}

S-1: Low sodium water can be used on almost all soils with little danger of accumulation of harmful amounts of exchangeable sodium.

S-2: Medium sodium water will present appreciable sodium hazard in soils of high clay content and low organic matter, especially under low leaching conditions, unless gypsum is present in the soil. This water can be used readily on coarse-textured soils with good permeability.

S-3: High sodium water will tend to cause harmful sodium accumulation in most nongypsiferous soils and will require special soil management. Good drainage, high leaching, and organic-matter additions for improving the physical conditions of the soil are necessary for success with these waters. Chemical amendments may be used for exchangeable sodium replacement except for waters of very high salinity, in which case, the use of amendments will not be feasible.

S-4: Very high sodium water will be generally unsatisfactory for irrigation purposes except at low and perhaps medium salinity where the use of gypsum or other amendments may be feasible. Waters high in salt and in the lower range of this class may keep the soil sufficiently flocculated to permit continuous"agriculture. Considerable leaching is required.

The RRGE Wells

The salt content of waters from RRGE-1, 2, and 3 are saltier than the water in the Raft River near the well area. The water from No. 3 is not suitable for irrigation and should not be discharged into the river. The other water can be used for the production of the relatively salt tolerant crops but water is required to leach the salts from the soil in order to maintain a salt balance. On some soils having a high water table, there may be a delicate balance between enough leaching to regulate the salt in the soil and too much leaching so as to raise the water table to a level where it has an adverse effect on the soil and the crops.

The sodium hazard of the waters is moderate to high. It is likely that if the well waters are used for irrigation, some of the soils will defloculate and the permeability of those soils will be greatly reduced.

Fluorides in the water pose a hazard to livestock that have access to the water. There is no problem with fluoride if the water is applied to the soil and not allowed to run off the land and into the river. Water passing through the soil will have most of the fluoride removed. 
Internal Distribution

1 - Chicago Patent Group - ERDA 9800 South Cass Avenue Argonne, Illinois 60439

3 - A. T. Morphew Ciassification and Technical Information Officer ERDA - ID Idaho Falls, Idaho 83401

1 - H. P. Pearson, Supervisor Technical Information

20 - Authors

35 - INEL Technical Library

\section{External Distribution}

$$
\begin{gathered}
508 \text { - UC-66g - Direct Applications of Heat from Geothermal } \\
\text { Resources, TID-4500, R65 }
\end{gathered}
$$

